\title{
Living at the Extremes: Extremophiles and the Limits of Life in a Planetary Context
}

\author{
Nancy Merino 1,2,3, Heidi S. Aronson ${ }^{4}$, Diana P. Bojanova ${ }^{1}$, Jayme Feyhl-Buska', \\ Michael L. Wong ${ }^{5,6}$, Shu Zhang ${ }^{7}$ and Donato Giovannelli ${ }^{2,8,9,10 *}$
}

\begin{abstract}
${ }^{1}$ Department of Earth Sciences, University of Southern California, Los Angeles, CA, United States, ${ }^{2}$ Earth-Life Science Institute, Tokyo Institute of Technology, Tokyo, Japan, ${ }^{3}$ Biosciences and Biotechnology Division, Physical and Life Sciences Directorate, Lawrence Livermore National Lab, Livermore, CA, United States, ${ }^{4}$ Department of Biology, University of Southern California, Los Angeles, CA, United States, ${ }^{5}$ Department of Astronomy - Astrobiology Program, University of Washington, Seattle, WA, United States, ${ }^{6}$ NASA Astrobiology Institute's Virtual Planetary Laboratory, University of Washington, Seattle, WA, United States, ${ }^{7}$ Section of Infection and Immunity, Herman Ostrow School of Dentistry of USC, University of Southern California, Los Angeles, CA, United States, ${ }^{8}$ Department of Biology, University of Naples "Federico II", Naples, Italy,

${ }^{9}$ Department of Marine and Coastal Science, Rutgers, The State University of New Jersey, New Brunswick, NJ, United States, ${ }^{10}$ Institute for Biological Resources and Marine Biotechnology, National Research Council of Italy, Ancona, Italy
\end{abstract}

OPEN ACCESS

Edited by:

Davide Zannoni,

University of Bologna, Italy

Reviewed by:

James A. Coker,

University of Maryland University

College, United States

Paola Di Donato,

University of Naples Parthenope, Italy

*Correspondence:

Donato Giovannelli

donato.giovannelli@unina.it

Specialty section:

This article was submitted to

Extreme Microbiology,

a section of the journal

Frontiers in Microbiology

Received: 11 January 2019 Accepted: 27 March 2019

Published: 15 April 2019

Citation:

Merino N, Aronson HS, Bojanova DP, Feyhl-Buska J,

Wong ML, Zhang $S$ and Giovannelli $D$

(2019) Living at the Extremes:

Extremophiles and the Limits of Life

in a Planetary Context.

Front. Microbiol. 10:780.

doi: 10.3389/fmicb.2019.00780
Prokaryotic life has dominated most of the evolutionary history of our planet, evolving to occupy virtually all available environmental niches. Extremophiles, especially those thriving under multiple extremes, represent a key area of research for multiple disciplines, spanning from the study of adaptations to harsh conditions, to the biogeochemical cycling of elements. Extremophile research also has implications for origin of life studies and the search for life on other planetary and celestial bodies. In this article, we will review the current state of knowledge for the biospace in which life operates on Earth and will discuss it in a planetary context, highlighting knowledge gaps and areas of opportunity.

Keywords: polyextremophiles, limits of life, astrobiology, habitability and astrobiology, extremophiles/ extremophily, search for life

\section{(POLY)EXTREMOPHILES HELP US PREDICT THE BOUNDARIES OF LIFE}

Over the past century, the boundary conditions under which life can thrive have been pushed in every possible direction, encompassing broader swaths of temperature, $\mathrm{pH}$, pressure, radiation, salinity, energy, and nutrient limitation. Microorganisms do not only thrive under such a broad spectrum of parameters on Earth, but can also survive the harsh conditions of space, an environment with extreme radiation, vacuum pressure, extremely variable temperature, and microgravity (Horneck et al., 2010; Yamagishi et al., 2018). The definition of "extreme conditions" has strong anthropocentric criteria, rather than microbial criteria, and can be the cause of confusion (Rothschild and Mancinelli, 2001). When considering extremophilic (as opposed to extremotolerant) organisms, it is important to keep in mind that these are highly adapted organisms for the conditions considered and that the "extreme" condition constitutes the norm under which the organism is able to metabolically and biochemically operate. Moreover, there are myriad environments on our planet's surface - and especially subsurface - that exhibit extremes in one or more physical or chemical condition. Therefore, extremophiles and, in particular, 
polyextremophiles (Capece et al., 2013) might be the most abundant lifeforms on our planet. In addition, if we consider that the current planetary surface conditions on Earth (such as mean temperature, redox state, and oxygenic atmosphere) have only occurred for a short period of time compared to the existence of life (Knoll, 2015), we might conclude that the extremophilic way of life has actually dominated the evolutionary history of life on our planet.

Over the past several decades, the isolation of culturable (poly)extremophiles and the identification of extreme microbial communities through various culture-independent approaches have provided key insights into the boundaries of life. Research on (poly)extremophiles has led to numerous advances in molecular biology and medicine (Babu et al., 2015; Coker, 2016; Durvasula and Rao, 2018), while simultaneously reshaping our understanding of the origins and evolution of life (Bertrand et al., 2015) and the potential for life on other planetary bodies (Schulze-Makuch, 2013). Several reviews have defined extremophiles (Table 1) (e.g., Rothschild and Mancinelli, 2001; Fang et al., 2010; Capece et al., 2013; Seckbach et al., 2013) and discussed the physiology and genetics of (poly)extremophiles in detail (e.g., chapters within Polyextremophiles: Life Under Multiple Forms of Stress, edited by Seckbach et al., 2013). To build upon these discussions, this paper will review the parameters that limit life, providing ranges under which life has been detected, herein defined as "boundary conditions." We will then map the currently known boundary conditions of life on Earth to the possible conditions or theoretical space that life could occupy on Earth. Finally, we will explore the prospect of using this information for the search of life on other planetary bodies.

\section{PARAMETERS THAT LIMIT LIFE}

Our knowledge of life is based on the observable and measurable phenomena that occur on Earth, and is therefore limited to this instance of life. However, the laws of chemistry and physics have universal principles which enable us to extrapolate to the conditions under which life could survive elsewhere. These principles suggest that life requires a liquid solvent, an energy source, and building blocks (Schwieterman et al., 2018).

While the bulk abundance of (inorganic) building blocks appears not to be a factor limiting the distribution of life on Earth (with subsurface environments as a possible exception, e.g., Hoehler and Jørgensen, 2013) and, potentially, other planetary bodies, the availability of a solvent is considered to be a key factor. While the potential for other liquid solvents to sustain extraterrestrial life is discussed in detail elsewhere (Schwieterman et al., 2018 and references therein), water is considered the most likely liquid solvent because of its cosmic abundance and physicochemical properties (Michiels et al., 2008; Schwieterman et al., 2018). Water, especially the availability of liquid water, appears to be the main factor controlling the dimensions of the biospace for life on Earth (i.e., the parameter space occupied by life). Liquid water acts both as a solvent and a reactant/product in biochemical reactions, and its numerous unique physicochemical properties have profoundly shaped the emergence and evolution of life on our planet. As discussed in this review below, water activity appears to be the single key parameter controlling the biospace of Earth's life, and numerous other parameters limiting life (e.g., temperature and salinity) are, in fact, acting on the availability of water. At the ecosystem level, water can indirectly influence the variation of key physicochemical conditions, which in turn controls microbial community composition and diversity, profoundly influencing geobiochemical cycling (sensu Shock and Boyd, 2015).

Life also needs a source of energy to power chemical reactions, and redox chemistry appears to be universal (Jelen et al., 2016). Physicochemical gradients create non-equilibrium redox conditions that have played an important role in the origins, evolution, and diversity of life. Redox and proton gradients were likely the two main mechanisms involved in the origins of life, initiating the necessary energy flux to drive metabolism and growth (Lane et al., 2010; Lane and Martin, 2012). Therefore, the current search for life's limits has extended beyond temperature, $\mathrm{pH}$, pressure, salinity, and radiation gradients (each parameter discussed in their respective sections) and also includes the possible energetic and nutrient limits of life (discussed in Hoehler and Jørgensen, 2013; LaRowe and Amend, 2015; Jones et al., 2018).

The parameters discussed herein (temperature, $\mathrm{pH}$, pressure, salinity, and radiation) correlate with each other and can influence the availability of nutrients and energy sources. Depending on the environment, certain parameters can more strongly influence microbial diversity over others, such as temperature in geothermal waters (Sharp et al., 2014), $\mathrm{pH}$ in soil communities (Rousk et al., 2010), salinity in saline lakes (Yang et al., 2016), and water content in dry climates (Dose et al., 2001). On the nano- and micro-scale level, the two most important factors are likely water activity and $\mathrm{pH}$, which influence the chemiosmotic, energy-generating gradient at the cell level (Lane et al., 2010; Lane and Martin, 2012). In contrast, parameters that influence the macro-scale level vary with the ecosystem. For example, temperature plays a significant role in geothermal environments and influences such processes as waterrock interactions and degassing (Nordstrom et al., 2005; Fouke, 2011; Cole et al., 2013; Price and Giovannelli, 2017). Waterrock interactions can then impact microorganisms by limiting the availability of trace elements and electron donors/acceptors.

Microorganisms have been detected in a variety of extreme environments (Figure 1), virtually in any location where liquid water is available for life to use. This demonstrates that life can adapt to a wide range of parameters (Figure 2). It is therefore imperative to determine the minima and maxima for each parameter, and even more importantly, to understand their combined effects, in order to evaluate the limits of Earth's life and advance our understanding of the potential for life elsewhere.

\section{Acidity and Alkalinity}

Extremely low and high $\mathrm{pH}$ environments have been observed for different ecosystems on Earth (Table 2). Extreme $\mathrm{pH}$ values were observed for ecosystems contaminated by mining waste, with current extremes reported from Iron Mountain (Shasta County, CA, United States) (pH -3.6) (Nordstrom et al., 2000) and Gorka 
TABLE 1 | Extremophiles nomenclature and ranges.

\begin{tabular}{|c|c|c|c|c|c|}
\hline \multirow[b]{2}{*}{$\mathrm{pH}$} & \multicolumn{5}{|c|}{ Low $\rightarrow$ High $^{a}$} \\
\hline & $\begin{array}{l}\text { Hyperacidophile } \\
(<\mathrm{pH} 3)\end{array}$ & $\begin{array}{l}\text { Acidophile } \\
(<\mathrm{pH} 5)\end{array}$ & $\begin{array}{l}\text { Neutrophile } \\
\text { (pH 5-9) }\end{array}$ & $\begin{array}{l}\text { Alkaliphile } \\
\text { (>pH 9) }\end{array}$ & $\begin{array}{l}\text { Hyperalkaliphile } \\
(>\mathrm{pH} 11)\end{array}$ \\
\hline Temperature & & $\begin{array}{l}\text { Psychrophile } \\
\left(<20^{\circ} \mathrm{C}\right)\end{array}$ & $\begin{array}{l}\text { Mesophile } \\
\left(20-45^{\circ} \mathrm{C}\right)\end{array}$ & $\begin{array}{l}\text { Thermophile } \\
\left(45-80^{\circ} \mathrm{C}\right)\end{array}$ & $\begin{array}{l}\text { Hyperthermophile } \\
\left(>80^{\circ} \mathrm{C}\right)\end{array}$ \\
\hline Salinity ${ }^{b}$ & & $\begin{array}{l}\text { Non-halophile } \\
(<1.2 \%)\end{array}$ & $\begin{array}{l}\text { Halotolerant } \\
(1.2-2.9 \% \text {; tolerate } \leq 14.6 \%)\end{array}$ & $\begin{array}{l}\text { Halophile } \\
(>8.8 \%)\end{array}$ & $\begin{array}{l}\text { Extreme halophile } \\
\text { (>14.6\%, cannot grow < 8.8\%) }\end{array}$ \\
\hline Pressure & & & $\begin{array}{l}\text { Piezotolerant or barotolerant } \\
(0.1-10 \mathrm{MPa})\end{array}$ & $\begin{array}{l}\text { Piezophile or barophile } \\
\text { (10-50 MPa) }\end{array}$ & $\begin{array}{l}\text { Hyperpiezophile or hyperbarophile } \\
\text { (>50 MPa) }\end{array}$ \\
\hline Water activity & & & Xerophile $\left(a_{w}<0.7\right)$ & & \\
\hline Polyextremophile & & & Tolerance or preference for multi & arameters combined & \\
\hline
\end{tabular}

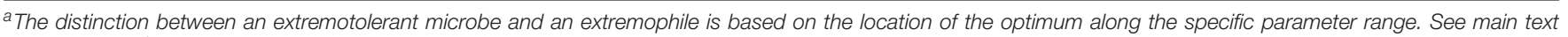

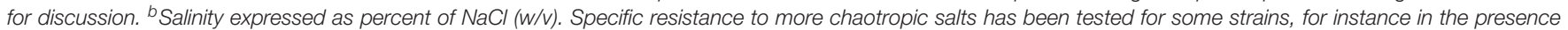
of $\mathrm{MgCl}_{2}$.

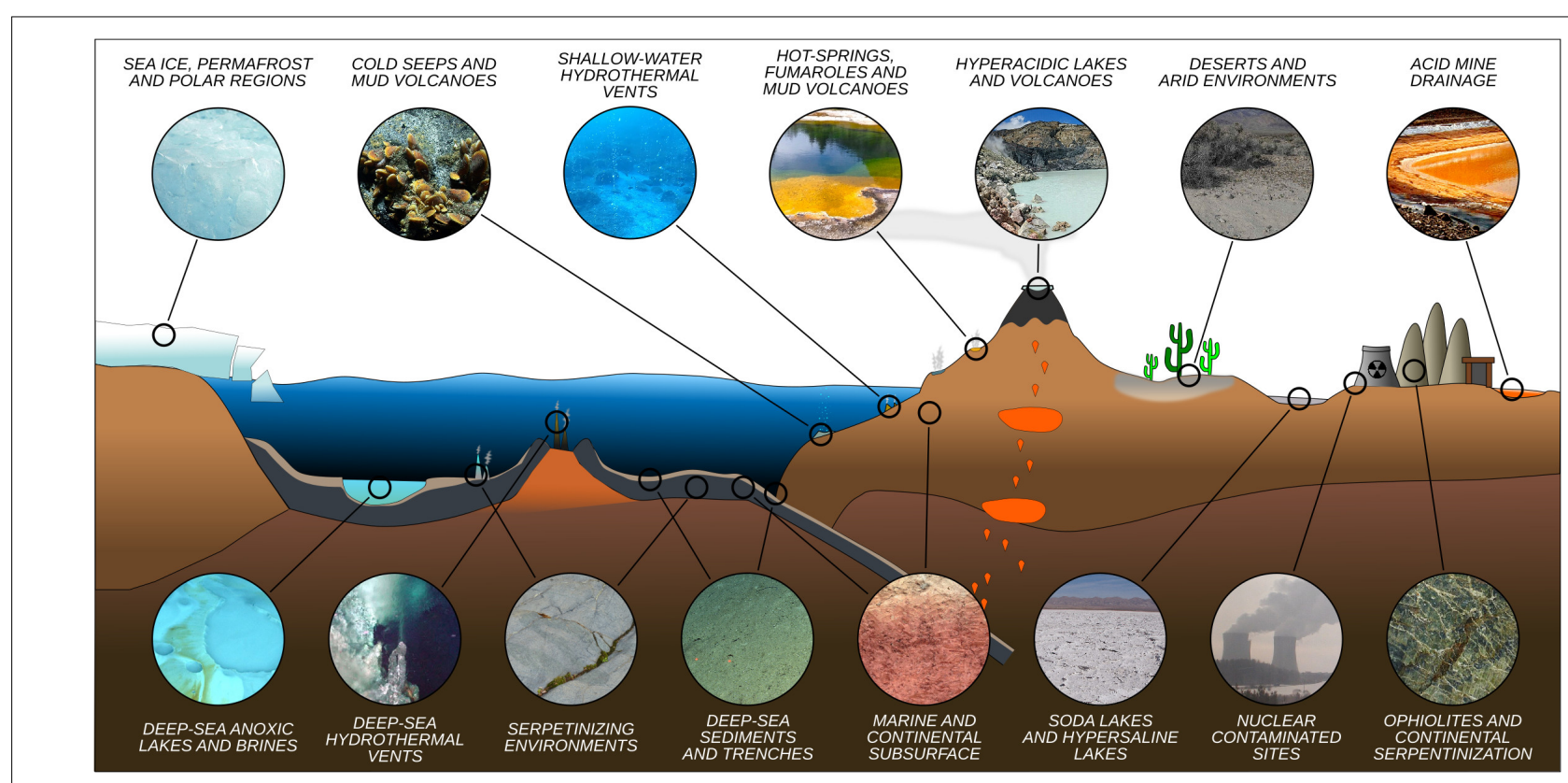

FIGURE 1 | Representative idealized cross section of Earth's crust showing the diversity of extreme environments and their approximate location.

Lake (Chrzanow region, Poland) ( $\mathrm{pH} \mathrm{13.3;} \mathrm{Czop} \mathrm{et} \mathrm{al.,} \mathrm{2011).}$ While there has yet to be any microbial community studies or isolation attempts for Gorka Lake, to the best of our knowledge, microbial communities have been explored at Iron Mountain (Baker and Banfield, 2003), with several microorganisms isolated [e.g., Thermoplasmales (Edwards et al., 2000), Acidithiobacillus ferrooxidans (Schrenk et al., 1998; Kelly and Wood, 2000), and Leptospirillum ferrooxidans (Schrenk et al., 1998)]. Despite this, there are currently no cultured or isolated microorganisms which can be grown at either of the listed extremes. Currently, the most extreme acidophile and alkaliphile can survive at $\mathrm{pH} 0$ and $\mathrm{pH}$ 12.5 , respectively $\left(\mathrm{pH}_{\mathrm{opt}} 0.7\right.$ and 11) (Table 3). The lowest $\mathrm{pH}_{\min }$ -0.06 was observed for two hyperacidophilic Archaea known as Picrophilus oshimae and P. torridus $\left(\mathrm{pH}_{\mathrm{opt}} 0.7\right)$, isolated from a solfataric hot spring in Noboribetsu (Hokkaido, Japan) (Schleper et al., 1996). These heterotrophic and aerobic polyextremophiles can also withstand temperatures of up to $65^{\circ} \mathrm{C}\left(T_{\text {opt }}=60^{\circ} \mathrm{C}\right.$, $T_{\min }=47^{\circ} \mathrm{C}$ ), potentially through increased cyclization of their tetraether membrane lipids as a generalized response to $\mathrm{pH}$, temperature, and nutrient stress (Feyhl-Buska et al., 2016). Other thermoacidophiles also include those species within the genus Sulfolobus, in which several isolates are known to be genetically tractable (Quehenberger et al., 2017). In comparison to extreme acidophily, the highest $\mathrm{pH}_{\max }$ of 12.5 was observed for an alkaliphilic, aerobic, mesophilic bacterium known as Serpentinomonas sp. B1 ( $\left.\mathrm{pH}_{\mathrm{opt}} 11\right)$, isolated from a terrestrial serpentinizing system, The Cedars (CA, United States) (Suzuki et al., 2014). Although there is a report of the highest $\mathrm{pH}_{\max }$ 13 held by Plectonema nostocorum (Kingsbury, 1954), this has not been further confirmed. The largest $\mathrm{pH}$ range, as compared to other isolated microorganisms, was observed for Halomonas campisalis $\left(\mathrm{pH}_{\text {range }} 6-12\right)$, a haloalkaliphilic bacterium isolated 


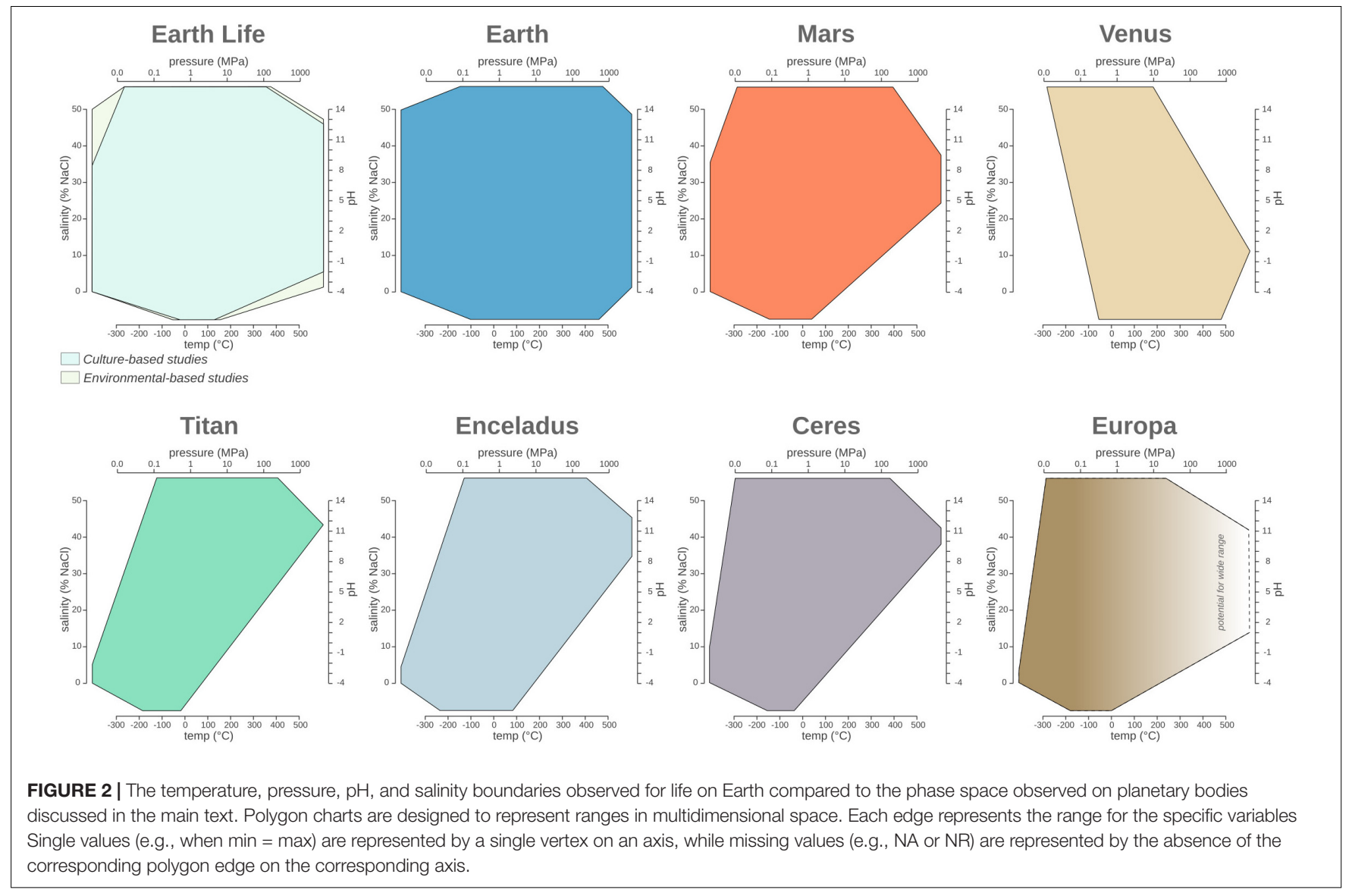

from a soda lake (Soap Lake, WA, United States) (Mormile et al., 1999; Aston and Peyton, 2007) (Table 4).

The $\mathrm{pH}$ has a significant effect on microorganisms and microbial consortia, ranging from the nano- to macro-scale level. All microorganisms must maintain a near neutral cytoplasmic $\mathrm{pH}$ to enable cellular functions for survival and metabolism (Krulwich et al., 2011; Jin and Kirk, 2018). The cytoplasmic $\mathrm{pH}$ of acidophilic bacteria is $\sim 6.0$ while alkaliphilic bacteria have a cytoplasmic pH around 7.2-8.7 (Krulwich et al., 2011). For more information on the molecular mechanisms behind pH homeostasis, Krulwich et al. (2011) provide a detailed review. The homeostasis of protons (and other ions) through various transporters, including the ion-utilizing ATP synthase, was likely one of the first functions to develop within the earliest cells (Lane and Martin, 2012). Indeed, chemiosmosis is a property of both archaeal and bacterial cells (Lane et al., 2010). In addition to intracellular $\mathrm{pH}$, microorganisms can excrete organic metabolites, such as lactic acid or acetic acid, thereby changing the immediate, surrounding $\mathrm{pH}$ (Zhang et al., 2016). Many acidophiles also have organic acid degradation pathways to prevent proton uncoupling by organic acids (BakerAustin and Dopson, 2007). It has been demonstrated both in natural settings and laboratory cultures that microorganisms can significantly alter their environmental $\mathrm{pH}$ as a result of metabolic reactions. For example, sulfide, thiosulfate, and elemental sulfur oxidizers secrete sulfate and protons as by-products, significantly acidifying their environment. This ability is used industrially for the bio-leaching of sulfide ore deposit (Olson et al., 2003; Rohwerder et al., 2003) and it is largely responsible for the low $\mathrm{pH}$ of acid mine drainage fluids and other acidic environments. Recent work by Colman et al. (2018) suggests that thermoacidophilic archaea and the acidity of their habitats co-evolved after the evolution of oxygenic photosynthesis (since oxygen is used as primary electron acceptor in the metabolisms), showing a significant example of niche engineering and geosphere-biosphere coevolution. All together, these findings suggest that $\mathrm{pH}$ can be metabolically controlled either at the intracellular or local level, as compared to temperature, radiation, salinity, and pressure.

On the macro-scale level, $\mathrm{pH}$ can dominate as the main parameter affecting microbial community composition and abundances. Several studies demonstrate that $\mathrm{pH}$ affects microbial community diversity more than any other parameter tested (e.g., Lauber et al., 2009; Rousk et al., 2010; Xiong et al., 2012; Kuang et al., 2013; Zhalnina et al., 2014). For example, distinct microbial communities were observed with changes in $\mathrm{pH}\left(\mathrm{pH}_{\text {range }} 1.9-4.1\right)$, in which the genus Ferrovum dominated at higher $\mathrm{pH}$ while the phyla Alphaproteobacteria, Gammaproteobacteria, Nitrospirae, and Euryarchaeota were present at lower pHs (Kuang et al., 2013). Similarly, bacterial community composition changed with increasing $\mathrm{pH}$ in alkaline 
TABLE 2 | Environmental boundary conditions for different Earth ecosystems.

\begin{tabular}{|c|c|c|c|c|c|}
\hline Biome & $\begin{array}{l}\text { Temperature } \\
\left({ }^{\circ} \mathrm{C}\right)\end{array}$ & $\mathrm{pH}$ & $\begin{array}{l}\text { Pressure } \\
\text { (MPa) }\end{array}$ & $\begin{array}{l}\text { Salinity } \\
(\% \mathrm{NaCl})\end{array}$ & References \\
\hline Soda lakes & $-0.5-83$ & $6.9-11.2^{\mathrm{a}}$ & $\mathrm{nr}$ & $0.64-37.1$ & $\begin{array}{l}\text { Jones et al., 1977; Tambekar et al., 2010; } \\
\text { Kavak and Karadogan, 2012; Pontefract et al., } \\
2017\end{array}$ \\
\hline $\begin{array}{l}\text { Terrestrial hot } \\
\text { springs/geothermal waters }\end{array}$ & $15-270$ & $0.02-9.8$ & $0.1-7.2^{b}$ & 0.0002-saturation & $\begin{array}{l}\text { Delmelle and Bernard, 1994; Namsaraev et al., } \\
\text { 2003; Taran, 2009; Chan et al., 2017; Qi et al., } \\
2017\end{array}$ \\
\hline Polar environments & $-98.6-24.3$ & $4.6-9.6$ & $0.1-35.5^{c}$ & $0-40.2$ & $\begin{array}{l}\text { Siegert et al., 2001; Aislabie et al., 2006; } \\
\text { Samarkin et al., 2010; Dickson et al., 2013; } \\
\text { Scambos et al., } 2018\end{array}$ \\
\hline $\begin{array}{l}\text { Deep-sea floor and } \\
\text { trenches }\end{array}$ & $-1.9-13.8^{d}$ & $7.3-8.1$ & $2.1-112$ & $3.4-3.9$ & $\begin{array}{l}\text { Mantyla and Reid, 1983; Emeis et al., 1996; } \\
\text { Danovaro et al., } 2010\end{array}$ \\
\hline $\begin{array}{l}\text { Deep-sea hydrothermal } \\
\text { vents }\end{array}$ & $<1^{\mathrm{e}}-464$ & $4-11$ & $2.1-50.7$ & $0.1-8$ & $\begin{array}{l}\text { Koschinsky et al., 2008; Konn et al., 2009; } \\
\text { McDermott et al., } 2018\end{array}$ \\
\hline $\begin{array}{l}\text { Deep hypersaline anoxic } \\
\text { basins }\end{array}$ & $10-65$ & $5.4-8.6$ & $2.1-40.5$ & $4-50^{f}$ & $\begin{array}{l}\text { Karbe, 1986; Yakimov et al., 2013, 2015; } \\
\text { Mapelli et al., 2017; Merlino et al., } 2018\end{array}$ \\
\hline Subsurface ecosystems & $3.25-<4009$ & $\sim 1-12.8$ & $<800^{h}$ & 0.05-saturation ${ }^{\mathrm{i}}$ & $\begin{array}{l}\text { Becker et al., 1984; Roadcap et al., 2006; } \\
\text { Waldron et al., 2007; Pankova and } \\
\text { Konyushkova, 2013; Lechmann et al., 2014; } \\
\text { Frank et al., 2016; Prieto et al., } 2017\end{array}$ \\
\hline Deserts $j$ & $-19.4-70$ & $6.8-10$ & $\mathrm{nr}$ & $0.02-30.8$ & $\begin{array}{l}\text { El-Demerdash et al., 1995; James et al., 2005; } \\
\text { Dion et al., 2008; Pandit et al., 2015; Holm } \\
\text { et al., } 2017\end{array}$ \\
\hline $\begin{array}{l}\text { Serpentinite-hosted } \\
\text { systems }^{k}\end{array}$ & 10-365 & $2.8-12.6$ & $<900^{\prime}$ & $0.03-49.68^{m}$ & $\begin{array}{l}\text { Scambelluri et al., 1997; Van Dover et al., 2001; } \\
\text { Mottl et al., 2003, 2004; Schrenk et al., 2013; } \\
\text { Suzuki et al., } 2013\end{array}$ \\
\hline Mine drainage & $1^{\mathrm{n}}-47$ & $-3.6-13.3$ & $6-14$ & $0.008-7.6$ & $\begin{array}{l}\text { Nordstrom et al., 2000; Tutu et al., 2008; Czop } \\
\text { et al., 2011; Miettinen et al., } 2015\end{array}$ \\
\hline
\end{tabular}

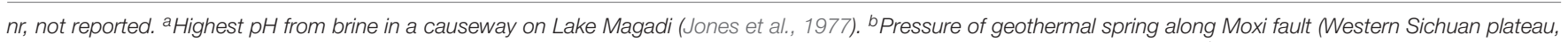

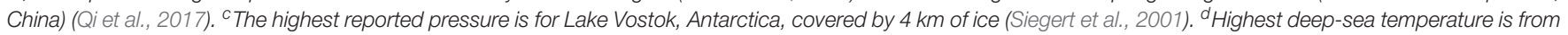

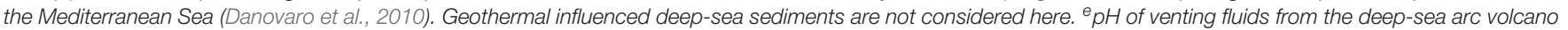

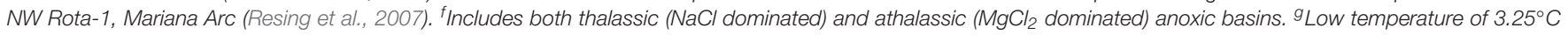

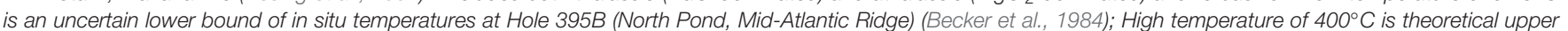

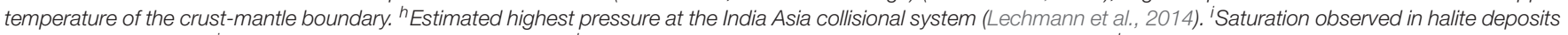

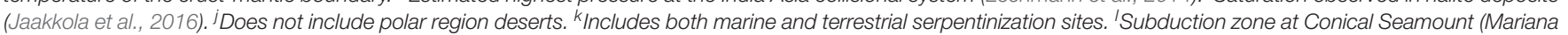

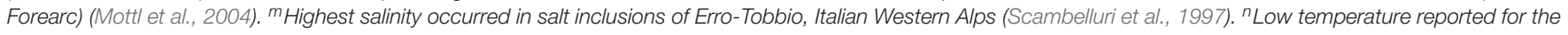
Gorka Pit Lake, Poland (Czop et al., 2011). ${ }^{\circ}$ Hydrostatic pressure of fluid fracture network in Pyhäsalmi mine, Finland (Miettinen et al., 2015).

sediments of a Tibetan plateau ( $\mathrm{pH}_{\text {range }}$ 6.88-10.37) (Xiong et al., 2012). Changes in community composition are likely derived from the range in which microorganisms can survive (Fernández-Calviño and Bååth, 2010). Most cultured microbes live within a narrow $\mathrm{pH}$ range of three to four units (Rosso et al., 1995), although some exceptions occur [e.g., fungal isolates can grow over five to nine $\mathrm{pH}$ units (Wheeler et al., 1991; Nevarez et al., 2009)]. Moreover, it has been suggested that archaeal (Kuang et al., 2013) and fungal communities (Rousk et al., 2010) may be less affected by changes in $\mathrm{pH}$ compared to bacteria.

\section{Salinity and Water Activity}

Salinity has a significant impact on microbial community composition (Lozupone and Knight, 2007; Swan et al., 2010). Saline environments comprise a large portion of the Earth and range from the marine environment ( $\sim 3-4 \%$ salinity), hot springs (up to $10.5 \%$ salinity), and to soda lakes (up to $37.1 \%$ salinity), and even salt inclusions [up to $49.7 \%$ salinity (Scambelluri et al., 1997)] (Figure 2 and Table 2). Salinity can also vary significantly on smaller scales, for example, in tidal pools (Morris and Taylor, 1983), or on salt mineral grains due to water deliquescence (Davila et al., 2008). A wide range of different ions, including $\mathrm{Na}^{++}, \mathrm{Cl}^{-}, \mathrm{SO}_{4}{ }^{2-}, \mathrm{Ca}^{2+}$, and $\mathrm{Mg}^{2+}$ (Oren, 2013) can contribute to total salinity in the environment. The ionic composition can significantly influence water activities, especially in the presence of high concentrations chaotropic salts, like in the athalassic deep-sea hypersaline anoxic basins of the Mediterranean Sea (Yakimov et al., 2015). In addition, water availability in terrestrial saline environments is further influenced by precipitation rates relative to evaporation, resulting in increasing concentration of salts (Finlayson et al., 2018).

The salinity range and optimum for cultivable and isolated microorganisms is between 0 and $35 \%$. The current highest salinity record holder is Halarsenatibacter silvermanii strain SLAS $-1^{\mathrm{T}}$, isolated from the alkaline hypersaline Searles Lake (CA, United States) (salinityopt 35\% NaCl) (Blum et al., 2009). Halophiles are found in all three domains of life (DasSarma and DasSarma, 2017). Current 


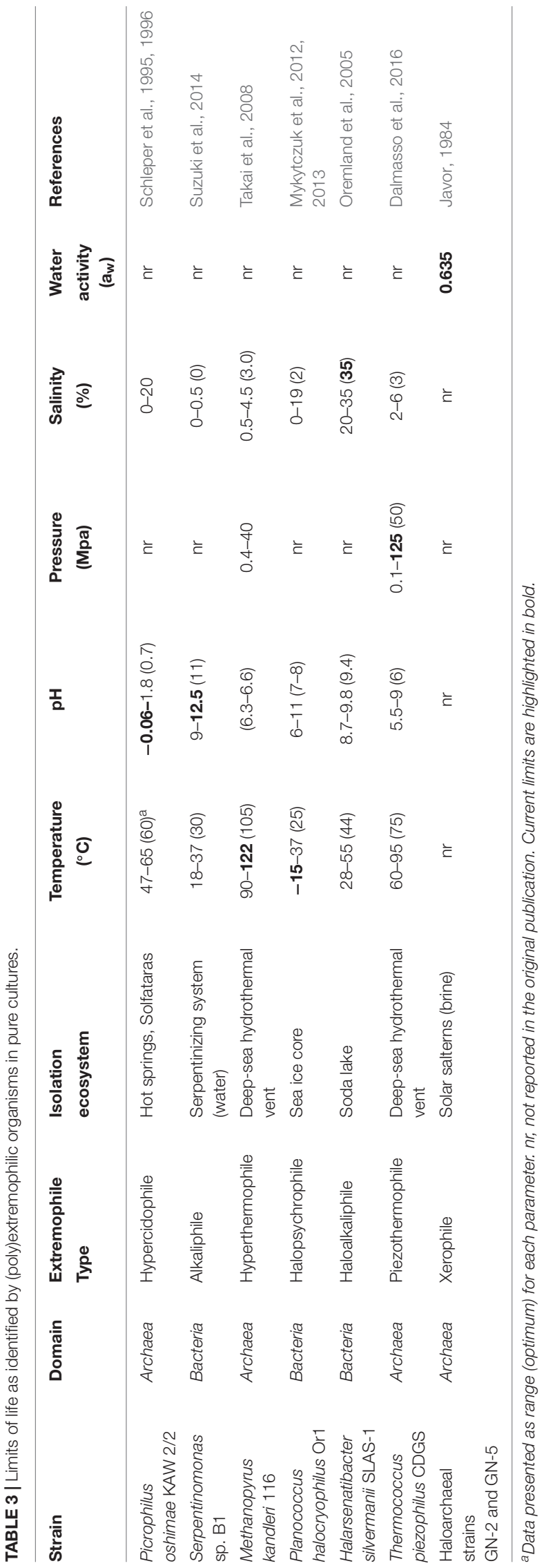

hyperhalophiles in culture include bacteria and archaea which can grow over a salinity of $\sim 15 \% \mathrm{NaCl}$. There are also polyextremophiles, for example, the bacterium Halomonas campisalis (Table 4), isolated from a soda lake (Soap Lake, WA, United States) is a moderate halophile and alkaliphile (salinity $\left.{ }_{\mathrm{opt}}=8.8 \%, \mathrm{pH}_{\mathrm{opt}}=9.5\right)$ and can tolerate extreme $\mathrm{pH}$ up to 12 and salinities up to 26.3\% (Mormile et al., 1999; Aston and Peyton, 2007).

Halophiles achieve the necessary osmotic balance by one of two strategies: (1) accumulating $\mathrm{K}^{+}$in the cytoplasm as a 'saltin' strategy or (2) excluding salts by synthesizing compatible organic solutes, such as polyols, amino acids, sugars, and betaines. The 'salt-in' strategy has been identified only in a few halophiles (e.g., Salinibacter and Halanaerobiales) which require $\mathrm{KCl}$ to have functional proteins. In contrast, many microorganisms that utilize the salt exclusion strategy can tolerate a wider range of salt concentrations due to the production of organic solutes to counter the concentration of salts (Oren, 2011). The necessary energy needed to maintain osmosis, and the thermodynamics of surviving under saline conditions have been thoroughly discussed by Oren (2011).

Many microorganisms in saline environments must also adapt to low water activity (the mole fraction of water) and increased radiation (discussed in section "Radiation"). Although salts can lower the freezing point of water, saturated salt solutions have low water activity. Water activity is the only other parameter, aside from $\mathrm{pH}$ and salinity, that some microorganisms can regulate through the production of metabolites capable of storing or attracting water (e.g., proteins and polysaccharides from EPS) (Frösler et al., 2017). The theoretical water activity minima for halophilic archaea and bacteria is $0.611 \mathrm{a}_{\mathrm{w}}$ while it is $0.632 \mathrm{a}_{\mathrm{w}}$ for fungi (Stevenson et al., 2015). In comparison, the water activity of $\mathrm{NaCl}$ saturated solutions is estimated to be $0.755 \mathrm{a}_{\mathrm{w}}$ while pure water is $1 \mathrm{a}_{\mathrm{w}}$ (Hallsworth et al., 2007; Stevenson et al., 2015).

The theoretical water activity limit has been surpassed by microbial life. When there are high concentrations of the chaotropic $\mathrm{MgCl}_{2}$ or $\mathrm{CaCl}_{2}$, the water activity is lowered even more (e.g., $0.3 \mathrm{a}_{\mathrm{w}}$ for a saturated $\mathrm{MgCl}_{2}$ solution). For example, environmental surveys reported microbial communities in the brines of two athalassic deep-sea hypersaline anoxic basin (DHAB), Discovery $\left(\mathrm{MgCl}_{2} \geq 5 \mathrm{M}, \mathrm{T}=14.5^{\circ} \mathrm{C}\right)$ (Van Der Wielen et al., 2005) and Kryos Basin (saturated $\mathrm{MgCl}_{2}, \sim 0.4$ $\mathrm{a}_{\mathrm{w}}, T=16.5^{\circ} \mathrm{C}$ ) (Alcaide et al., 2015; Steinle et al., 2018), both located in the Mediterranean Sea. The Kryos Basin microbial community, located in the brine, consisted of active sulfatereducers, with sulfate reduction reaching up to $460 \mu \mathrm{mol} / \mathrm{kg}$-day (Steinle et al., 2018). In contrast to the DHABs, microbial life has yet to be shown to exist in a $\mathrm{CaCl}_{2}$-dominated brine with up to $474 \mathrm{~g} / \mathrm{L}$ total dissolved salts (Don Juan Pond, Antarctica) (Oren, 2013). This is likely due to both extreme temperature and salinity conditions, as Don Juan Pond is an unfrozen lake $(\mathrm{pH}$ 4.6) with an average depth of $11 \mathrm{~cm}$ and temperatures reaching below $-36^{\circ} \mathrm{C}\left(T_{\max } \sim 20^{\circ} \mathrm{C}\right)$ (Torii et al., 1981; Samarkin et al., 2010; Dickson et al., 2013). The estimated water activity in Don Juan Pond is likely below $0.45 \mathrm{a}_{\mathrm{w}}$ (Oren, 2013) but could be between $0.28 \mathrm{a}_{\mathrm{w}}\left(25^{\circ} \mathrm{C}\right)$ to $0.61 \mathrm{a}_{\mathrm{w}}\left(-50^{\circ} \mathrm{C}\right)$, as estimated 
TABLE 4 | Examples of notable (Poly)extremophiles and their physiological requirements.

\begin{tabular}{|c|c|c|c|c|c|c|c|c|}
\hline Strain & Domain & $\begin{array}{l}\text { Extremophile } \\
\text { type }\end{array}$ & $\begin{array}{l}\text { Isolation } \\
\text { ecosystem }\end{array}$ & $\begin{array}{l}\text { Temperature } \\
\left({ }^{\circ} \mathrm{C}\right)\end{array}$ & $\mathrm{pH}$ & $\begin{array}{l}\text { Pressure } \\
\text { (MPa) }\end{array}$ & $\begin{array}{l}\text { Salinity } \\
(\%)\end{array}$ & References \\
\hline Acidianus infernus So4a & Archaea & Acidothermophile & Solfatara crater & 65-96 (90) & $1-5.5(2)$ & na & 0.2 (na) & Segerer et al., 1986 \\
\hline $\begin{array}{l}\text { Colwellia piezophila ATCC } \\
\text { BAA-637 }\end{array}$ & Bacteria & Piezopsychrophile & Deep-sea & $4-15(10)$ & 7 (na) & $40-80(60)$ & na (3) & Nogi et al., 2004 \\
\hline $\begin{array}{l}\text { Halomonas campisalis } \\
\text { MCM B-365 }\end{array}$ & Bacteria & Hyperalkaliphile & Soda lake & $4-50(30)$ & $6-12(9.5)$ & na & $1.1-26.3$ (8.9) & Aston and Peyton, 2007 \\
\hline $\begin{array}{l}\text { Oceanobacillus iheyensis } \\
\text { HTE831 }\end{array}$ & Bacteria & $\begin{array}{l}\text { Alkaliphile, } \\
\text { piezotolerant, and } \\
\text { halotolerant }\end{array}$ & Deep-sea (mud) & $15-42(30)$ & $6.5-10(7-9.5)$ & $0.1-30$ & 0-21 (3) & Lu et al., 2001 \\
\hline $\begin{array}{l}\text { Anoxybacillus } \\
\text { pushchinensis K1 }\end{array}$ & Bacteria & Alkalithermophile & Manure & $37-66(62)$ & 8-10.5 (9.5) & na & $<3(n a)$ & Pikuta et al., 2000 \\
\hline $\begin{array}{l}\text { Actinopolyspora righensis } \\
\mathrm{H} 23\end{array}$ & Bacteria & Halophile & Saline soil & 20-40 (28-32) & $5-8(6-7)$ & na & $10-30(15-25)$ & Meklat et al., 2013 \\
\hline $\begin{array}{l}\text { "Geothermobacterium } \\
\text { ferrireducens" FW-1a }\end{array}$ & Bacteria & Hyperthermophile & $\begin{array}{l}\text { Obsidian Pool, } \\
\text { Yellowstone National } \\
\text { Park }\end{array}$ & 65-100 (85) & na & na & 0 (na) & Kashefi et al., 2002 \\
\hline $\begin{array}{l}\text { Shewanella piezotolerans } \\
\text { WP3 }\end{array}$ & Bacteria & Piezophile & Deep-sea & 0-28 (15-20) & $6-8(7)$ & $0.1-50(20)$ & $1-7.2(3-4)$ & Xiao et al., 2007 \\
\hline Colwellia sp. MT-41 & Bacteria & Piezopsychrophile & Deep-sea & 2 (na) & 6.8 (na) & $51.8-103.5$ (69) & na & Yayanos et al., 1981 \\
\hline Pedobacter arcticus A12 & Bacteria & Psychrophile & Tundra (soil) & 4-25 (18) & $6-9(7)$ & na & 0-2 (0) & Zhou et al., 2012 \\
\hline $\begin{array}{l}\text { Thermococcus } \\
\text { gammatolerans EJ3 }\end{array}$ & Archaea & $\begin{array}{l}\text { Thermophile and } \\
\text { radiation-tolerant }\end{array}$ & $\begin{array}{l}\text { Hydrothermal vent } \\
\text { (chimney) }\end{array}$ & 55-95 (88) & na (5.5-6.5) & na & (20) & Jolivet et al., 2003 \\
\hline $\begin{array}{l}\text { Deinococcus radiodurans } \\
\text { R1 }\end{array}$ & Bacteria & $\begin{array}{l}\text { Vacuum- and } \\
\text { radiation-tolerant }\end{array}$ & Spoiled canned meat & \multicolumn{4}{|c|}{ Mars-like conditions, vacuum, UV and space radiation } & De Vera et al., 2012 \\
\hline $\begin{array}{l}\text { Cryomyces antarcticus } \\
\text { MA5682 }\end{array}$ & Fungi & $\begin{array}{l}\text { Vacuum- and } \\
\text { radiation-tolerant }\end{array}$ & Antarctica & \multicolumn{4}{|c|}{ Mars-like conditions, vacuum, UV and space radiation } & De Vera et al., 2012 \\
\hline $\begin{array}{l}\text { Deinococcus geothermalis } \\
\text { DSM } 11300\end{array}$ & Bacteria & Xerotolerant & Hot spring & $30-55(47)$ & $5-8(6.5)$ & na & na & Frösler et al., 2017 \\
\hline $\begin{array}{l}\text { Halobacterium salinarum } \\
\text { NRC-1 }\end{array}$ & Archaea & $\begin{array}{l}\text { Xerotolerant, } \\
\text { vacuum- and } \\
\text { radiation-tolerant }\end{array}$ & $\begin{array}{l}\text { Bore core from a salt } \\
\text { mine }\end{array}$ & 42 (na) & na & na & 25 & Kottemann et al., 2005 \\
\hline
\end{tabular}


for a $\mathrm{CaCl}_{2}$-dominated brine with antarcticite $\left(\mathrm{CaCl}_{2} \cdot 6 \mathrm{H}_{2} \mathrm{O}\right)$ precipitation (Toner et al., 2017).

\section{Temperature}

The temperature on Earth's surface ranges from -98.6 to $495^{\circ} \mathrm{C}$ [ultra-cold locations in East Antarctica (Scambos et al., 2018) and extremely hot deep-sea hydrothermal vents (McDermott et al., 2018)], with much higher temperatures possible in magma influenced subsurface environments (Table 2). Fluid temperatures above $100^{\circ} \mathrm{C}$ are possible whenever the combination of hydrothermal or magmatic activity is present together with high pressure, for example, in the deep subsurface near volcanoes or at deep-sea hydrothermal vents. In the absence of geothermal influence, the highest surface temperature reported on Earth is $\sim 71^{\circ} \mathrm{C}$, in the Lut Desert (Iran) (Mildrexler et al., 2011). The current temperature extreme that microbial life can survive extends from $-25^{\circ} \mathrm{C}\left(T_{\min }\right.$, Deinococcus geothermalis DSM 11300) (Frösler et al., 2017) to $130^{\circ} \mathrm{C}$ ( $T_{\max }$, "Geogemma barossii" 121) (Kashefi and Lovley, 2003) (Table 4). Around $-26^{\circ} \mathrm{C}$ to $-10^{\circ} \mathrm{C}$, microbial cells will likely become vitrified (without intracellular freezing), enabling cells to survive low temperatures (Clarke et al., 2013). The temperature range in which microorganisms are reported to be metabolically active is currently between $-20^{\circ} \mathrm{C}$ (an enrichment culture from the Siberian permafrost soil) (Rivkina et al., 2000) and $122^{\circ} \mathrm{C}$ (Methanopyrus kandleri 116; Takai et al., 2008). In comparison, the lowest temperature in which a pure culture isolate is capable of growing is $-15^{\circ} \mathrm{C}$ with $18 \%$ salinity (Planococcus halocryophilus Or1; Mykytczuk et al., 2012, 2013).

The upper temperature of life has been raised several times in the past 50 years of research (Brock and Freeze, 1969; Ferrera and Reysenbach, 2007), and current environmental and theoretical studies suggest that the upper limit of life might lay near $\sim 150^{\circ} \mathrm{C}$, due primarily to the instability of macromolecules above this temperature. Similarly, thermodynamic considerations suggest that life might be impossible below $-40^{\circ} \mathrm{C}$ (Price and Sowers, 2004), thus the current theoretical boundaries for life are $-40^{\circ} \mathrm{C}$ to $150^{\circ} \mathrm{C}$. It is still possible, however, that the boundary conditions of life might extend past these limits, and the surpassing of previous historical theoretical limits suggest that future studies might unveil unexpected adaptation strategies.

Extreme temperature adaptations by psychrophiles and thermophiles generally involve either high saline or pressure conditions. High saline, cold environments enable the growth of halopsychrophiles (Deming, 2007). Liquid inclusions in sea ice are due to the high concentrations of salts, which lower the freezing point of water, and this liquid fraction can still be observed at $-40^{\circ} \mathrm{C}$ (theoretical seawater eutectic temperature is $-55^{\circ} \mathrm{C}$ ) (Deming, 2007). Microbial consortia are likely to inhabit subzero brine veins, especially those surrounding soil particles, where salts and organic materials (e.g., the microbially produced extracellular polymeric substances or EPS) are concentrated. Indeed, the majority of active bacteria and archaea observed in Arctic wintertime sea-ice cores at $-20^{\circ} \mathrm{C}$ were all particle-associated (Junge et al., 2004). In contrast to halopsychrophiles, there are very few halothermophiles, with a combined temperature range of $17-70^{\circ} \mathrm{C}\left(T_{\text {opt }}=50-65^{\circ} \mathrm{C}\right)$ and salinity range $2.9-29.2 \%$ (salinity ${ }_{\mathrm{opt}}=11.7-26.3 \% \mathrm{NaCl}$ ) (Mesbah and Wiegel, 2005). Several hyperthermophiles (growth at $>80^{\circ} \mathrm{C}$ ) must grow at high pressure conditions because high pressure allows water to remain liquid at higher temperatures, with an upper theoretical limit of $407^{\circ} \mathrm{C}$ at $29.8 \mathrm{MPa}$ pressure (Koschinsky et al., 2008; McDermott et al., 2018). Hyperthermopiezophilic microorganisms, such as Methanopyrus kandleri strain 116 (Takai et al., 2008) and "Geogemma barossii" strain 121 (Kashefi and Lovley, 2003) (Table 4), are able to maintain cell structural integrity due to the contrasting effects of high temperature and high pressure.

Macro-scale temperature gradients demonstrate the influence of temperature on microbial community composition within an ecosystem (Purcell et al., 2007; Miller et al., 2009; Everroad et al., 2012; Cole et al., 2013; Sharp et al., 2014). In this regard, the effect of increasing temperature gradients, especially in geothermalinfluenced environments, have been studied to greater extent compared to decreasing temperature gradients. In general, the community complexity decreases with increasing temperatures on the scale of centimeters to meters. For example, the soil microbial community of Tengchong Geothermal Field (China) shifted toward lower diversity with increasing temperatures (50$90.2^{\circ} \mathrm{C}$ and $32-36 \mathrm{MPa}$ ) and became dominated by Archaea (Li et al., 2015). Similar patterns have been also reported for deep-sea and shallow-water hydrothermal vents (Flores et al., 2012; Giovannelli et al., 2013). Temperature gradients likely have more influence on the microbial community of geothermal environments (Sharp et al., 2014), as compared to other environments (e.g., soil), where $\mathrm{pH}$ and salinity have been shown to be the dominant factor (see sections "Acidity and Alkalinity" and "Salinity and Water Activity").

\section{Pressure}

As mentioned above, pressure influences microbial growth, especially under extreme temperatures. On Earth's surface, pressure ranges from 0.1 to $112 \mathrm{MPa}$ (Table 2), with higher pressures observed at subduction zones (e.g., $900 \mathrm{MPa}$ at the top of a subducting plate, Mariana Forearc; Mottl et al., 2004) and subsurface environments (e.g., Miettinen et al., 2015). It is estimated that microbial life could be supported at subduction zone forearcs with pressures $\sim 340 \mathrm{MPa}$ (Plümper et al., 2017). Several piezophiles and piezotolerant microorganisms have been isolated from deep-sea locations (Table 3), and the current record holder is Thermococcus piezophilus, a thermophilic Archaeon able to survive up to $125 \mathrm{MPa}\left(P_{\mathrm{opt}}=50 \mathrm{MPa}, P_{\text {growth range }}=0.1-\right.$ $125 \mathrm{MPa}$ ) (Dalmasso et al., 2016). Piezophiles have lower generation times at higher pressure than at atmospheric pressure (Bartlett et al., 2007), and considering the average depth of the ocean is $3,800 \mathrm{~m}$ (average pressure $38 \mathrm{MPa}$ ), with bottom temperatures between 0 and $3^{\circ} \mathrm{C}$, there is likely a vast number of uncultured piezophiles across a range of temperatures, including a vast majority of psychropiezophiles (Alazard et al., 2003; Fang et al., 2010). Despite the small number of strict piezophiles currently in culture, environmental studies suggest that life can easily accommodate high pressures, and studies on piezotolerant strains have demonstrated that life can survive brief exposures up to 2,000 MPa (Sharma et al., 2002; Vanlint et al., 2011). 
Under these extreme conditions, cells have been shown to be metabolically active in fluid inclusions found in ice-VI crystals within diamond anvil cells (Sharma et al., 2002).

(Hyper)piezophiles have adapted to extreme pressures through various strategies. In particular, the cell membrane is packed with more unsaturated fatty acids to increase membrane fluidity at high pressures. Other adaptations could include upregulation chaperone-encoding genes, modification of the respiratory chain, expression of different porins, and production of osmolytes (Oger and Jebbar, 2010; Jebbar et al., 2015). Several detailed reviews on piezophile adaptation strategies are available, including Fang et al. (2010), Oger and Jebbar (2010), Picard and Daniel (2013), and Jebbar et al. (2015).

In contrast to high pressure environments, the low pressure found at high altitude in mountain formations $(0.0033 \mathrm{MPa}$ at the summit of Mount Everest) is unlikely to affect microbial survival per se, and the lowest pressure is found in space vacuum or low Earth orbit $\left(10^{-13}\right.$ to $10^{-10} \mathrm{MPa}$ ) (Horneck et al., 2010). Despite this, several prokaryotes, fungi, and lichen can survive exposure for several months to years under space conditions (Horneck et al., 2010; De Vera et al., 2012; Onofri et al., 2018; Yamagishi et al., 2018), due to sporulation or formation of biofilms (Frösler et al., 2017). It is possible that the top layer of a biofilm protects the lower layers, enabling the survival of microorganisms under space conditions. For example, Deinococcus aetherius ST survived a 1-year exposure to space conditions only when $\geq 500 \mu \mathrm{m}$ cell layer was utilized (Yamagishi et al., 2018). However, longer exposure to space vacuum can cause detrimental effects, such as dehydration and DNA denaturation, and likely requires pre-dried microbial spores or biofilm within a protective substance (e.g., sugars or buffer salts). For more information, Horneck et al. (2010) have written a detailed review on space condition effects on microorganisms.

The effects of pressure on microbial community composition can be observed most obviously in deep-sea environments. However, it is likely that other parameters dominate as the major contributors to community composition and abundances, such as salinity, temperature, oxygen concentrations, and UV radiation (Amend and Shock, 2001; Phoenix et al., 2006; Walsh et al., 2016), rather than pressure. In contrast to deepsea environments, there have been few studies examining the microbial community diversity with increasing elevation, where surface air pressure decreases with altitude. However, it is still likely that other parameters affect microorganisms, as suggested by the change in bacterial diversity with elevation at Mount Fuji (Japan) (Singh et al., 2012). The highest bacterial diversity was observed at $2,500 \mathrm{~m}$, along the tree line, and declined toward $\sim 3,700 \mathrm{~m}$ (near the summit), where extreme temperatures, UV radiation, and a lack of nutrients likely affected the microbial community more significantly than pressure changes. In addition, the Earth's atmosphere is a unique ecosystem that enables the distribution of microorganisms $\left(\sim 10^{2}-10^{5}\right.$ cells $/ \mathrm{mL}$ in cloud or fog) through aerosolization (Delort et al., 2010; DasSarma and DasSarma, 2018). In the atmosphere, microorganisms have to contend with multiple hazards, including UV-C and cosmic radiation, low temperatures, desiccation, and oxidants (DasSarma and DasSarma, 2018), and it is unlikely that decreasing pressure plays the most significant role in microbial community diversity (Amato et al., 2007). Under these conditions, sporulation, resting stages, and biofilm formation are strategies used to withstand the multiple extremes (Delort et al., 2010).

\section{Radiation}

Radiation sources include UV radiation, X-rays, gamma rays and more generally, cosmic rays. These different types of ionizing radiation, in particular UV and gamma rays, can impact microbial cells via direct and indirect (e.g., the formation of reactive oxygen species) mechanisms. The reactive oxygen species can then damage DNA, proteins, lipids, and RNA, in addition to initiating Fenton-type reactions within the cell due to the release of $\mathrm{Fe}^{2+}$ from $\mathrm{Fe}-\mathrm{S}$ clusters (Webb and DiRuggiero, 2013). Radiation-resistant microorganisms have been shown to resist up to $30 \mathrm{kGy}$ of $\gamma$-radiation, in the case of a thermophilic bacterium Thermococcus gammatolerans EJ3 (Jolivet et al., 2003) and a mesophilic bacterium Deinococcus hohokamensis (Rainey et al., 2005) and 100-1000 J/m² of UV254, in a xerotolerant bacterium Psychrobacter pacificensis L0S3S03b (La Duc et al., 2007). One of the first radiation-resistant microorganisms isolated was Deinococcus radiodurans, which has been well-studied and regarded as a model organism for understanding radiation tolerance (Krisko and Radman, 2013). Additionally, these microorganisms are often polyextremophiles (Table 4) (Fredrickson et al., 2008; Webb and DiRuggiero, 2013).

Many ecosystems on Earth are affected by some type of radiation, with the most extreme radiation emanating from human-made radioactive-contaminated sites. These range from $0.5 \mathrm{~Bq} / \mathrm{kg}$ at the Great Lakes, United States (Trapeznikov, 1983) to $10^{9} \mathrm{~Bq} / \mathrm{kg}$ at Hanford Site in Richland, WA, United States (Fredrickson et al., 2004). Radiation can additionally be found in subsurface environments, due to the radioactive decay of radiogenic isotopes (e.g., ${ }^{238} \mathrm{U},{ }^{232} \mathrm{Th}$, and ${ }^{40} \mathrm{~K}$ ), which could also be responsible for radiolytic hydrogen production (Dzaugis et al., 2016), potentially supporting in situ microbial productivity. Indeed, a hyperthermophilic and radiation-tolerant archaeon was isolated (Thermococcus gammatolerans EJ3) from a deepsea hydrothermal environment located at the East Pacific Rise, where natural radioactivity occurs $\left({ }^{210} \mathrm{~Pb},{ }^{210} \mathrm{Po},{ }^{222} \mathrm{Rn}\right)$ (Jolivet et al., 2003).

There are several isolated microorganisms which can survive exposure to extreme radiation ( $\mathrm{kGy}$ ), including exposure to space conditions for hundreds of days (De Vera et al., 2012). UV radiation likely influenced the evolution of life, especially during the Archean, when the ozone layer had yet to develop in the upper atmosphere due to a lack of atmospheric $\mathrm{O}_{2}$. During this time, there were also intervals in which a photochemically produced organic haze would form, creating a UV shield (Arney et al., 2016). As such, the earliest life would have to contend with periods of intense UV radiation until enough $\mathrm{O}_{2}$ was produced by oxygenic phototrophs after the Great Oxidation Event (ca. 2.8-2.4 Ga). Through photochemical reactions at short UV radiation wavelengths $(<242 \mathrm{~nm})$, a protective ozone layer could be established, thus preventing a significant amount of short wavelength $(<290 \mathrm{~nm})$ radiation from penetrating to the 
surface (Caldwell et al., 1989; Phoenix et al., 2006). It is likely that microorganisms had to develop the necessary resistance to both UV and ionizing radiation. Indeed, model simulations demonstrate that the 200-300 $\mathrm{nm}$ wavelength range were several orders of magnitude higher about 4-3.5 Ga compared to current levels (Cnossen et al., 2007; Cockell and Raven, 2007), and as mentioned previously T. gammatolerans EJ3 was isolated from an environment with natural radioactivity (Jolivet et al., 2003). Microbial adaptions to radiation include more genome copies for genome redundancy (Anitori, 2012, chapter 2), changes in DNA repair functions (Byrne et al., 2014), a condensed nucleoid (Anitori, 2012, chapter 2), utilization of smaller amino acids (Sghaier et al., 2013), accumulation of Mn(II) (Daly et al., 2004), production of pigments (Mojib et al., 2013), and more, as described elsewhere (Confalonieri and Sommer, 2011; Anitori, 2012; Krisko and Radman, 2013). These adaptations are seen throughout the microbial tree of life; for example, two mutants of Halobacterium sp. NRC-1, which can tolerate extreme radiation levels $\left(\mathrm{LD}_{50}>11 \mathrm{kGy}\right)$, had upregulation of a protein complex known to be involved in DNA repair, replication and recombination (DeVeaux et al., 2007). This complex is closely related to the archaeal and eukaryotic protein known as RPA (replication protein A) and to the bacterial protein SSB (singlestrand DNA-binding protein). Although radiation resistance has been observed throughout Archaea, Bacteria, and Eukarya, the origins and evolution of such adaptations to radiation has yet to be determined.

\section{POTENTIAL EXPANDED RANGES FOR LIFE}

Earth's ecosystems often have wider ranges for each of the environmental parameters considered in this review compared to the current known limits for life (Figure 2). As described in the previous sections, the physical and chemical conditions of Earth's environments exhibit a wide range, much of which, but not all, has been shown to be exploited by microbial life. Since the first extremophile discoveries in 1969, each decade of exploration has broadened our view of the boundaries of microbial environmental habitability. Therefore, it is likely that the true limits of life have yet to be found. For example, observed limits for temperature are $-20-130^{\circ} \mathrm{C}$, the theoretical temperature limit is considered to be between -40 and $150^{\circ} \mathrm{C}$ due to decreasing metabolic rates at $-40^{\circ} \mathrm{C}(\sim 100$ million years to turn over all of the cellular carbon; Price and Sowers, 2004) and the denaturation of cellular components is at $150^{\circ} \mathrm{C}$ (SchulzeMakuch et al., 2017 and references therein). The ability of life to adapt and thrive under extreme conditions can be further supported by the analysis of the communities adapted to $\mathrm{pH}$ changes caused by human activity, including the dumping of mine drainage and steel slag. Earth's natural ecosystems have a $\mathrm{pH}$ range of $0.02-12.5$, but contaminated sites extend the range to $\mathrm{pH}-3.6-13.3$ and have observable microbial communities (Méndez-García et al., 2015) (Table 2). Similar to pH, the current pressure range of microbial life $\left(P_{\text {range }} 0.1-125 \mathrm{MPa}\right)$ extends beyond that of Earth's surface ecosystems $\left(P_{\text {range }} 0.1-112 \mathrm{MPa}\right)$, demonstrating life can resist more extreme values of both low and high pressure (see section "Pressure"). Similarly, microorganisms living in extreme salinity ( salinity $_{\text {life }}=0-35 \%$, salinity Earth $=0$ $50 \%)$ also need to contend with water activity. As mentioned previously, the lowest $\mathrm{a}_{\mathrm{w}}$ for life is currently estimated $\sim 0.611 \mathrm{a}_{\mathrm{w}}$ (Stevenson et al., 2015), but microbial life surpassed this water activity limit in DHABs $\left(\sim 0.4 \mathrm{a}_{\mathrm{w}}\right)$ (see section "Salinity and Water Activity").

Although there are many (poly)extremophiles currently in culture (see Table 4 for some examples of notable polyextremophiles), data concerning the ability to withstand multiple stressors are extremely limited (Harrison et al., 2013). Moreover, the number of cultured microorganisms is tiny if compared to the diversity of uncultured clades (Hug et al., 2016). The number of uncultured microorganisms at the genus level has been recently estimated to be on average $7.3 \times 10^{29}$, with $\sim 81 \%$ of microbial cells in environments such as the terrestrial subsurface, hypersaline environments, marine sediment, hot springs, and hydrothermal vents (Lloyd et al., 2018). These uncultivated microorganisms are very likely to include (poly)extremophiles and will aid in expanding our understanding of the boundary conditions of life.

\section{CAN LIFE ORIGINATE, EVOLVE, OR SURVIVE ON OTHER PLANETARY BODIES?}

Different classification schemes have been published to describe planetary bodies based on their 'habitability' (e.g., Lammer et al., 2009; Noack et al., 2016; Schulze-Makuch et al., 2017). Several studies have also demonstrated the growth of microorganisms under lab-simulated planetary conditions, including Mars-like (Nicholson et al., 2013; Schuerger and Nicholson, 2016; FajardoCavazos et al., 2018) and Enceladus-like (Taubner et al., 2018) conditions. In this context, defining the boundary limits of life on Earth is a crucial step in identifying the conditions likely to originate or support life on other planetary bodies. Therefore, studies on the limits of life are important to understand four areas: (1) the potential for panspermia, (2) forward contamination due to human exploration ventures, (3) planetary colonization by humans, and (4) the exploration of extinct and extant life. In this review, we outline the physical and chemical boundary conditions of Earth's environments and those of life on Earth and compare them to the conditions observed on other planetary bodies in order to discuss whether life could originate, evolve, or survive elsewhere in our solar system and beyond.

Similar to Earth, other planetary bodies might have different environments with varying ranges for each parameter. Since our knowledge of individual niches or habitats is extremely limited for other planetary bodies, we considered the range of each parameter (temperature, salinity, $\mathrm{pH}$, and pressure) across three planetary layers: (1) atmosphere, (2) surface, and (3) subsurface (Table 5). Many planetary bodies studied thus far have the potential for extinct or extant life, based on our knowledge of life on Earth. Depending on the planetary 
TABLE 5 | Boundary conditions for different planetary bodies of astrobiological interest (compared to Earth), split into atmosphere, surface, and subsurface layers.

\begin{tabular}{|c|c|c|c|c|c|c|c|c|}
\hline $\begin{array}{l}\text { Planetary } \\
\text { body }\end{array}$ & Type & Layer & $\begin{array}{c}\text { Temperature } \\
\left({ }^{\circ} \mathrm{C}\right)\end{array}$ & $\mathrm{pH}$ & $\begin{array}{l}\text { Pressure } \\
\text { (MPa) }\end{array}$ & $\begin{array}{c}\text { Salinity } \\
(\% \mathrm{NaCl})\end{array}$ & Geochemistry & References \\
\hline \multirow[t]{3}{*}{ Earth } & Planet & Atmosphere & $-100-40$ & $\begin{array}{l}\text { Neutral, local } \\
\text { acidic } \\
\text { conditions } \\
\text { possible due to } \\
\text { volcanism and } \\
\text { human } \\
\text { activities }\end{array}$ & $0.0001-0.1$ & 0 & 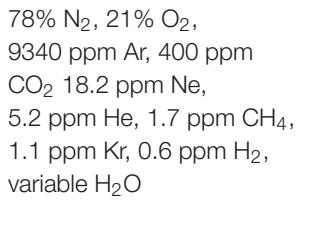 & $\begin{array}{l}\text { Hans Wedepohl, 1995; } \\
\text { McDonough and Sun, } \\
\text { 1995; Wayne, } 2000\end{array}$ \\
\hline & & Surface & $-98.6-464$ & $-3.6-13.3$ & $0.003-112$ & $\begin{array}{c}0- \\
\text { saturation }\end{array}$ & $\begin{array}{l}\text { Soils and sediments of } \\
\text { varying lithologies, siliceous } \\
\text { crust, ranging from mafic to } \\
\text { felsic composition. } \\
\text { Extensive ocean ( } 70 \% \\
\text { planet surface), with } 4,000 \\
\mathrm{~m} \text { average depth, } 4{ }^{\circ} \mathrm{C} \text { and } \\
3.5 \% \text { average temperature } \\
\text { and salinity respectively }\end{array}$ & \\
\hline & & Subsurface & $3.25-<400$ & $\sim 1-12.8$ & $<800$ & $\begin{array}{c}0.05- \\
\text { saturation }\end{array}$ & $\begin{array}{l}\text { Soils and sediments of } \\
\text { varying lithologies, siliceous } \\
\text { crust, ranging from mafic to } \\
\text { felsic composition, } \\
\text { ultramafic mantle }\end{array}$ & \\
\hline \multirow[t]{3}{*}{ Venus } & Planet & Atmosphere & $-40-482^{a}$ & $0^{\mathrm{b}}$ & $0.1-9.3^{c}$ & $\mathrm{nr}$ & $\begin{array}{l}96.5 \% \mathrm{CO}_{2}, 3.5 \% \mathrm{~N}_{2} \\
\text { small quantities of } \mathrm{CO} \text {, } \\
\mathrm{SO}_{2}, \mathrm{HCl}, \mathrm{HF}, \mathrm{HDO} \text {, and } \\
\mathrm{H}_{2} \mathrm{O} ; \mathrm{H}_{2} \mathrm{SO}_{4} \text { condensates }\end{array}$ & $\begin{array}{l}\text { Cockell, 1999; } \\
\text { Basilevsky and Head, } \\
\text { 2003; Schulze-Makuch } \\
\text { et al., 2004; Lang and } \\
\text { Hansen, 2006; Bertaux } \\
\text { et al., 2007; Airey et al., } \\
2017\end{array}$ \\
\hline & & Surface & $377-482$ & $\mathrm{nr}$ & $4.5-9.3^{\mathrm{C}}$ & $\mathrm{nr}$ & $\begin{array}{l}\text { Rocks are similar to } \\
\text { tholeiitic and alkaline } \\
\text { basalts; no liquid water }\end{array}$ & \\
\hline & & Subsurface & $\mathrm{nr}$ & $\mathrm{nr}$ & $\mathrm{nr}$ & $\mathrm{nr}$ & Fluid channels; volcanism & \\
\hline Mars & Planet & Atmosphere & $-138-35^{d}$ & $\mathrm{nr}$ & $0.0001-0.0009$ & $\mathrm{nr}$ & $\begin{array}{l}95.3 \% \mathrm{CO}_{2}, 2.7 \% \mathrm{~N}_{2} \\
1.6 \% \mathrm{Ar}, 0.13 \% \mathrm{O}_{2}, 0.08 \% \\
\mathrm{CO} \text {; trace amounts of } \mathrm{H}_{2} \mathrm{O} \text {, } \\
\mathrm{NO}, \mathrm{Ne}, \mathrm{Kr}, \mathrm{Xe}\end{array}$ & $\begin{array}{l}\text { Varnes et al., 2003; } \\
\text { Fairén et al., 2004; } \\
\text { Nicholson and } \\
\text { Schuerger, 2005; } \\
\text { Hecht et al., 2009; } \\
\text { Smith et al., 2009; } \\
\text { Johnson et al., 2011; } \\
\text { Jones et al., 2011; } \\
\text { Michalski et al., 2013; } \\
\text { Longstaff, 2014; } \\
\text { Wordsworth, 2016; } \\
\text { Sinha et al., 2017; } \\
\text { NASA, 2018 }\end{array}$ \\
\hline
\end{tabular}


TABLE 5 | Continued

\begin{tabular}{|c|c|c|c|c|c|c|c|c|}
\hline $\begin{array}{l}\text { Planetary } \\
\text { body }\end{array}$ & Type & Layer & $\begin{array}{c}\text { Temperature } \\
\left({ }^{\circ} \mathrm{C}\right)\end{array}$ & $\mathrm{pH}$ & $\begin{array}{c}\text { Pressure } \\
\text { (MPa) }\end{array}$ & $\begin{array}{l}\text { Salinity } \\
(\% \mathrm{NaCl})\end{array}$ & Geochemistry & References \\
\hline & & Surface & $-138-30$ & $7.7^{e}$ & $0.0004-0.0009$ & $5.2-5.8$ & $\begin{array}{l}\text { Basaltic, Fe-/Mg-rich } \\
\text { phyllosilicates, perchlorate } \\
\text { salts, Al-rich clays, sulfates, } \\
\text { chlorides, calcite, and } \\
\text { silicas; potential cryosphere }\end{array}$ & \\
\hline & & Subsurface & $55^{9}$ & $4.96-9.13^{h}$ & $10-303^{9}$ & $\begin{array}{l}\mathrm{Cl} \text {-rich } \\
\text { brines }\end{array}$ & $\begin{array}{l}\text { Potential groundwater; } \\
\text { basalt crust; possible } \\
\text { serpentinization }\end{array}$ & \\
\hline \multirow[t]{3}{*}{ Enceladus } & Icy moon & Plume jets & 0 & $\sim 8.5-9$ & $\begin{array}{l}\text { High velocity } \\
\text { jets }\end{array}$ & $>0.5$ & $\begin{array}{l}90-99 \% \mathrm{H}_{2} \mathrm{O}, \\
\leq 0.61-4.27 \% \mathrm{~N}_{2} \text {, } \\
0.3-5.3 \% \mathrm{CO}_{2}, 0.1-1.68 \% \\
\mathrm{CH}_{4}, 0.4-0.9 \% \mathrm{NH}_{3} \text {, } \\
0.4-39 \% \mathrm{H}_{2} \text {, trace } \\
\text { amounts of hydrocarbons; } \\
\text { high mass organic cations, } \\
\text { silicates, sodium, } \\
\text { potassium, carbonates }\end{array}$ & $\begin{array}{l}\text { Gioia et al., 2007; } \\
\text { Postberg et al., 2009, } \\
\text { 2018; Waite et al., } \\
\text { 2009; Zolotov et al., } \\
\text { 2011; Glein et al., } \\
\text { 2015; Holm et al., } \\
\text { 2015; Hsu et al., 2015; } \\
\text { Taubner et al., } 2018\end{array}$ \\
\hline & & $\begin{array}{c}\text { Icy shell } \\
(\sim 10 \mathrm{~km} \text { thick })\end{array}$ & $-233--23$ & $\mathrm{nr}$ & $\mathrm{nr}$ & $\begin{array}{c}\text { May have } \\
\text { ammonia } \\
\text { brine } \\
\text { pockets }\end{array}$ & May have tectonics & \\
\hline & & $\begin{array}{l}\text { Subsurface } \\
\text { global ocean } \\
(\sim 0-170 \mathrm{~km} \\
\text { depth) }\end{array}$ & $<90$ & $8.5-12.2^{k}$ & $1-8$ & $0.45-<4$ & Possible serpentinization & \\
\hline \multirow[t]{2}{*}{ Titan } & Icy moon & Atmosphere & $-183--73^{j}$ & $\mathrm{nr}$ & $>0.01-0.15$ & $\mathrm{nr}$ & $\begin{array}{l}98.4 \% \mathrm{~N}_{2}, 1.4 \% \mathrm{CH}_{4}, \\
0.2 \% \mathrm{H}_{2} \text {, trace } \\
\text { hydrocarbons and } \\
\text { organics; } \sim 50 \text { ppmv } \mathrm{CO} \\
\text { and } \sim 15 \mathrm{ppbv} \mathrm{CO}_{2} ; \mathrm{HCN} \text {, } \\
\mathrm{C}_{2} \mathrm{H}_{3} \mathrm{CN} \text {, and other nitriles; } \\
\text { hazes and clouds }\end{array}$ & $\begin{array}{l}\text { Fulchignoni et al., } \\
\text { 2005; de Kok et al., } \\
\text { 2007; Norman, 2011; } \\
\text { Baland et al., 2014; } \\
\text { Mastrogiuseppe et al., } \\
\text { 2014; Mitri et al., 2014; } \\
\text { Sohl et al., 2014; } \\
\text { Jennings et al., 2016; } \\
\text { McKay, 2016; Mitchell } \\
\text { and Lora, 2016; Brassé } \\
\text { et al., 2017; Cordier } \\
\text { et al., } 2017\end{array}$ \\
\hline & & Surface & $-183--179$ & $\mathrm{nr}$ & $0.15-0.35^{i}$ & $\mathrm{nr}$ & $\begin{array}{l}95 \% \mathrm{~N}_{2}, 5 \% \mathrm{CH}_{4}, 0.1 \% \\
\mathrm{H}_{2} ; \text { lakes and sea have } \\
\mathrm{CH}_{4}, \mathrm{C}_{2} \mathrm{H}_{4} \text {, and dissolved } \\
\text { nitrogen; dunes of solid } \\
\text { organic material; } \\
\text { low-latitude deserts and } \\
\text { high-latitude moist climates }\end{array}$ & \\
\hline
\end{tabular}


TABLE 5 | Continued

\begin{tabular}{|c|c|c|c|c|c|c|c|c|}
\hline $\begin{array}{l}\text { Planetary } \\
\text { body }\end{array}$ & Type & Layer & $\begin{array}{c}\text { Temperature } \\
\left({ }^{\circ} \mathrm{C}\right)\end{array}$ & $\mathrm{pH}$ & $\begin{array}{l}\text { Pressure } \\
\text { (MPa) }\end{array}$ & $\begin{array}{l}\text { Salinity } \\
(\% \mathrm{NaCl})\end{array}$ & Geochemistry & References \\
\hline & & Subsurface & -18 & $11.8^{1}$ & $50-300^{m}$ & $\begin{array}{c}\text { Likely } \\
\text { dense } \\
\text { subsurface } \\
\text { ocean } \\
(\leq 1,350 \mathrm{~kg} \\
\left.\mathrm{m}^{-3}\right) \\
\text { suggesting } \\
\text { high salinity }\end{array}$ & $\mathrm{CH}_{4}$ and $\mathrm{C}_{2} \mathrm{H}_{6}$ & \\
\hline \multirow[t]{3}{*}{ Ceres } & $\begin{array}{l}\text { Dwarf } \\
\text { planet }\end{array}$ & Atmosphere & $\mathrm{nr}$ & $\mathrm{nr}$ & $\mathrm{nr}$ & $\mathrm{nr}$ & $\begin{array}{l}\text { Transient atmosphere with } \\
\text { possible water vapor }\end{array}$ & $\begin{array}{l}\text { Fanale and Salvail, } \\
\text { 1989; Zolotov, 2009, } \\
\text { 2017; Küppers et al., } \\
\text { 2014; Hayne and } \\
\text { Aharonson, 2015; } \\
\text { Neveu and Desch, } \\
\text { 2015; Hendrix et al., } \\
\text { 2016; Villarreal et al., } \\
\text { 2017; Vu et al., 2017; } \\
\text { Castillo-Rogez et al., } \\
\text { 2018; McCord and } \\
\text { Castillo-Rogez, 2018; } \\
\text { McCord and Zambon, } \\
\text { 2019 }\end{array}$ \\
\hline & & Surface & $(-157--30)^{n}$ & $9.7-11.3^{n}$ & $\mathrm{nr}$ & $<10^{n}$ & $\begin{array}{l}\text { Surface clays; (Mg, } \\
\mathrm{Ca} \text {-carbonates; (Mg, } \\
\mathrm{NH}_{4} \text { )-phyllosilicates; Fe-rich } \\
\text { clays; salt deposits; } \\
\text { chloride salts; water-rock } \\
\text { interactions; brucite and } \\
\text { magnetite; sulfur species } \\
\text { and graphitized carbon; } \\
\text { localized } \mathrm{Na} \text {-carbonates } \\
\left(\text { e.g., } \mathrm{Na}_{2} \mathrm{CO}_{3}\right), \mathrm{NH}_{4} \mathrm{Cl} \text {, } \\
\mathrm{NH}_{4} \mathrm{HCO}_{3}\end{array}$ & \\
\hline & & Subsurface & $-143--93^{\circ}$ & Likely alkaline & $<140-200^{p}$ & $\begin{array}{l}\text { Potentially } \\
\text { has briny or } \\
\mathrm{NH}_{3} \text {-rich } \\
\text { subsurface } \\
\quad \text { liquid }\end{array}$ & $\begin{array}{l}\text { Active water/ice-driven } \\
\text { subsurface processes }\end{array}$ & \\
\hline Europa & Icy moon & $\begin{array}{l}\text { Atmosphere } \\
\text { (tenuous) }\end{array}$ & $\mathrm{nr}$ & $\mathrm{nr}$ & $0.1^{-12}-1^{-12}$ & $\mathrm{nr}$ & $\begin{array}{l}\text { Ion sputtering of the } \\
\text { surface; potential water } \\
\text { plumes; } \mathrm{O}_{2} \text {; trace amounts } \\
\text { of sodium and potassium }\end{array}$ & $\begin{array}{l}\text { Spencer et al., 1999; } \\
\text { Chyba and Phillips, } \\
\text { 2001; Marion et al., } \\
\text { 2005; McGrath et al., } \\
\text { 2009; Zolotov and } \\
\text { Kargel, 2009; }\end{array}$ \\
\hline
\end{tabular}


TABLE 5 | Continued

\begin{tabular}{|c|c|c|c|c|c|c|c|c|}
\hline $\begin{array}{l}\text { Planetary } \\
\text { body }\end{array}$ & Type & Layer & $\begin{array}{c}\text { Temperature } \\
\left({ }^{\circ} \mathrm{C}\right)\end{array}$ & $\mathrm{pH}$ & $\begin{array}{l}\text { Pressure } \\
\text { (MPa) }\end{array}$ & $\begin{array}{l}\text { Salinity } \\
\text { (\% NaCl) }\end{array}$ & Geochemistry & References \\
\hline & & & & & & & & $\begin{array}{l}\text { Travis et al., 2012; } \\
\text { Cassidy et al., 2013; } \\
\text { Muñoz-Iglesias et al., } \\
\text { 2013; Kattenhorn and } \\
\text { Prockter, 2014; } \\
\text { Soderlund et al., 2014; } \\
\text { Hand and Carlson, } \\
\text { 2015; Kimura and } \\
\text { Kitadai, 2015; Noell } \\
\text { et al., 2015; Vance } \\
\text { et al., 2016; Teolis } \\
\text { et al., 2017; Zhu et al., } \\
\text { 2017; Jones et al., } \\
\text { 2018; Martin and } \\
\text { McMinn, 2018; Pavlov } \\
\text { et al., 2018 }\end{array}$ \\
\hline & & $\begin{array}{l}\text { Surface (icy } \\
\text { shell) }\end{array}$ & $-187--141$ & $\mathrm{nr}$ & $0.1^{-12}$ & $\begin{array}{l}\text { May be } \\
\text { saline, as } \\
\text { delivered to } \\
\text { the surface } \\
\text { from a salty } \\
\text { ocean, may } \\
\text { have brine } \\
\text { or salt } \\
\text { inclusions }\end{array}$ & $\begin{array}{l}\mathrm{H}_{2} \mathrm{O}_{2}, \mathrm{H}_{2} \mathrm{SO}_{4}, \mathrm{CO}_{2} \text {; salts } \\
\text { concentrated in cracks; } \\
\text { oxidants and simple } \\
\text { organics; potentially } \\
\mathrm{MgSO}_{4}, \mathrm{Na}_{2} \mathrm{SO}_{4}, \mathrm{Na}_{2} \mathrm{CO}_{3} \text {, } \\
\text { may have gas inclusions; } \\
\text { may have tectonics }\end{array}$ & \\
\hline & & $\begin{array}{l}\text { Subsurface } \\
\text { ocean }\end{array}$ & $\begin{array}{c}\text { Daily inundation } \\
\text { of seawater at } \\
T=-4-0\end{array}$ & $\begin{array}{l}\text { Potential for } \\
\text { wide range }\end{array}$ & $0.1-30^{r}$ & $<3.5$ & $\begin{array}{l}\text { Likely contains } \mathrm{Mg}^{2+} \text {, } \\
\mathrm{SO}_{4}{ }^{2-}, \mathrm{Na}^{+}, \mathrm{Cl}^{-} ; \text {oxidants } \\
\text { and simple organics }\end{array}$ & \\
\hline
\end{tabular}

The observed or putative geochemistry as well as other potential influences are also listed. ${ }^{2}$ Thermosphere can be as cold as $-173^{\circ} \mathrm{C}$ (Bertaux et al., 2007); the upper-to-middle cloud layers are between -40 and $60^{\circ} \mathrm{C}$ (Cockell, 1999). ${ }^{b}$ Acid concentration in upper cloud layer is 81\%, in lower layers up to 98\% (Cockell, 1999). ' Up to 11 MPa in a deep depression (Basilevsky and Head, 2003). ${ }^{d}$ Summer air temperatures on Mars near the equator can reach a maximum of $35^{\circ} \mathrm{C}$ (Longstaff, 2014). ${ }^{\circledR}$ Measured by the Phoenix Mars Lander Wet Chemistry Laboratory at the northern plains of the Vastitas Borealis (Hecht et al., 2009). ${ }^{f}$ Liquid water

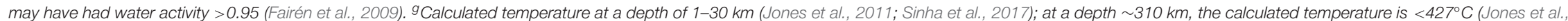
2011): the Martian core has temperature $1,527^{\circ} \mathrm{C}$ (Longstaff, 2014). " $\mathrm{C} C$ alculated groundwater $\mathrm{pH}$ Narnes et al., 2003). 'Calculated pressure at Titan's large sea, Ligeia Mare, is 0.20-0.35 MPa (Cordier et al., 2017). jTropospheric temperature can be $-193^{\circ} \mathrm{C} ; 80 \%$ of incident sunlight is absorbed by Titan's atmosphere, suggesting that there are greenhouse and antigreenhouse effects (Mitchell and Lora, 2016). ${ }^{k}$ The subsurface ocean on Enceladus could also have pH range 10.8-13.5 (Glein et al., 2015). ' 'Calculated ocean pH with 5 wt\% $\mathrm{NH}_{3}$ (Brassé et al., 2017). ${ }^{2}$ Calculated pressure for the subsurface ocean with thickness $100 \mathrm{~km}$ and outer shell thickness 40-170 km (Baland et al., 2014); $800 \mathrm{MPa}$ at the mantle ice shell-core boundary (Sohl et al., 2014). ${ }^{n}$ Calculated surface temperatures, illuminated surfaces can have temperature $<-173^{\circ} \mathrm{C}$ (Hayne and Aharonson, 2015); calculated pH and salinity for bright deposits in Occator crater (Zolotov, 2017); temperature for bright deposits in Occator crater might reach <-0.2 ${ }^{\circ} \mathrm{C}$ (Zolotov, 2017). ${ }^{\circ}$ Internal temperature might reach $77^{\circ} \mathrm{C}$ (McCord and Sotin, 2005). 'PCeres' center pressure (Zolotov, 2009). 'A Acid brine may result from hydrothermal systems and be enriched with sulfuric acid (Kargel et al., 2000); neutral brine may occur as leachate from chondritic material and be enriched with magnesium sulfate (Kargel et al., 2000; Pasek and Greenberg, 2012); alkaline brine may occur in areas with natron ( $\mathrm{Na}_{2} \mathrm{CO}_{3} \cdot{ }^{\cdot 10 \mathrm{H}}{ }_{2} \mathrm{O}$ ), produced from the venting of $\mathrm{CO}_{2}$ from aqueous reservoirs (Langmuir, 1971; Millero and Rabindra, 1997). ' ${ }^{2}$ t the base of a $100 \mathrm{~km}$ Europan ocean, the pressure is calculated to be $146 \mathrm{MPa}$ (Marion et al., 2005). 
body, different (poly)extremophiles could persist. For example, halopsychrophiles might be able to persist on Titan, Ceres, and Europa, which likely have saline subsurface oceans (Grindrod et al., 2008; Zolotov and Kargel, 2009; Neveu and Desch, 2015), and also on Mars which could have Cl-rich subsurface brines (Clifford et al., 2010; Jones et al., 2011). These lifeforms would also need to withstand high pressures. For example, the hydrostatic pressure of the subsurface ocean at Titan ranges from 140 to $800 \mathrm{MPa}$ (Sohl et al., 2014). While such pressures are beyond the range of the most extreme cultured piezophile on Earth (Thermococcus piezophilus, $P_{\max }=125 \mathrm{MPa}$ ) (Dalmasso et al., 2016), microorganisms have successfully been exposed to pressures up to 2,000 $\mathrm{MPa}$ and found to be metabolically active in fluid inclusions within type-IV ice (Vanlint et al., 2011). Based on these observations it is possible that other planetary bodies may be within reach for Earth-based life (Table 5), including Enceladus $\left(P_{\max }=50 \mathrm{MPa}\right.$; Hsu et al., 2015) and Europa $\left(P_{\max }=30 \mathrm{MPa}\right.$; Muñoz-Iglesias et al., 2013).

The atmospheres of some planetary bodies could potentially harbor life as well. In particular, the upper-to-middle cloud layers of Venus $\left(0-60^{\circ} \mathrm{C} ; \mathrm{pH} \sim 0\right)$ might be suitable for thermo- or psychro-acidophilic microorganisms (Table 4). Titan also has a dense atmosphere, but it is extremely cold $\left(-183--78^{\circ} \mathrm{C}\right)$ and life on Earth can only metabolize at temperatures greater than $-20^{\circ} \mathrm{C}$ (Rivkina et al., 2000). Other planetary bodies presented in Table 5 have transient or tenuous atmospheres that have extremely low pressures and likely cannot support life. In comparison, on Earth, microorganisms have been observed and cultured from the upper atmosphere, although stresses such as UV-C radiation, low temperatures, and oxidants make it difficult to survive (DasSarma and DasSarma, 2018). Microorganisms, in particular psychrophiles, with the capability of biofilm formation, clumping, and repair systems are more likely to tolerate Earth's atmospheric conditions (DasSarma and DasSarma, 2018). Similar strategies may be needed on other planetary bodies.

The surface of other planetary bodies, such as Ceres, Europa, and Mars, experience high levels of radiation, and thus, may be unsuitable to support life. UV radiation is damaging for Earthbased life, and several studies have shown that there is a $99 \%$ loss in viability for microorganisms placed under Mars-like surface conditions, with UV-C as the most harmful source (Schuerger et al., 2003). However, shielding from UV-C radiation increases the chance of survival and includes shielding by atmospheric dust or burial (Barbier et al., 1998; Mancinelli and Klovstad, 2000; Cockell et al., 2002, 2005; Schuerger et al., 2003; Hansen et al., 2009; Johnson et al., 2011). Shielding is also necessary against charged particle radiation and can be achieved by burial at only centimeter depths below the surface. Indeed, the harsh radiation exposed to Europa's surface inside the Jovian magnetosphere is predicted to only penetrate about $1-20 \mathrm{~cm}$ below the surface of Europa, as modeled by Nordheim et al. (2018).

Solar and galactic cosmic rays (high-energy particles with energies from $10 \mathrm{MeV}$ to $>10 \mathrm{GeV}$ ) present challenges to life on the surface and near-surface of Mars and other planetary bodies. However, any subsurface aquifer deeper than a few meters would be protected from damaging radiation. Dartnell et al. (2007) calculated the galactic cosmic ray dosage rates and the corresponding survival times (which they defined as a million-fold decrease in cell number) of characteristic microbes at different depths in Mars's subsurface. At the surface, E. coli has a survival time of 1,200 years, while at 20-m depth, that survival time jumps to $1.5 \times 10^{8}$ years. Compared to E. coli, D. radiodurans has survival times an order of magnitude longer. These survival times are, in fact, lower limits in light of recent measurements by the Radiation Assessment Detector onboard the Mars Science Laboratory (Hassler et al., 2014), which found that the actual dose rate at Gale Crater $\left(76 \mathrm{mGy} \mathrm{year}^{-1}\right)$ is a factor of 2 lower than that modeled by Dartnell et al. (2007).

With respect to cosmic rays, early Mars would have provided more favorable environments: Mars's ancient dynamo may have produced a global magnetic field on the order of that of the present-day Earth (Weiss et al., 2008), and a thicker atmosphere would have also provided significantly impeded a flux of highenergy particles. Ehresmann et al. (2011) found that, with an atmosphere 100 times as thick, the dose rate at the surface decreases to $\sim 0.3-20 \%$ of its present-day value.

In addition to radiation, the surface of other planetary bodies is generally extremely cold. The minimum estimated temperature all planetary bodies listed in Table 5, except for Venus, ranges from $-138^{\circ} \mathrm{C}$ (Mars) to $-233^{\circ} \mathrm{C}$ (Enceladus) while the maximum estimated temperature ranges from $-179^{\circ} \mathrm{C}$ (Titan) to $30^{\circ} \mathrm{C}$ (Mars). In accordance, the average temperature of satellites that are potential analogs to Earth is much less than $-5^{\circ} \mathrm{C}$, with many satellites likely experiencing wide temperature variation (Reid et al., 2006). This indicates the physiology of radiation-tolerant psychrophiles is important for understanding the potential of life on the surface of other planetary bodies, such as the production of a fibril network, cell aggregation, and cold shock proteins (Reid et al., 2006).

This suggests the subsurface is one of the most important locations in the search for extinct and extant extraterrestrial life (Jones et al., 2018). On Earth alone, the subsurface is estimated to house $50-87 \%$ of the Earth's microorganisms (Kallmeyer et al., 2012; Magnabosco et al., 2018). The subsurface of other planetary bodies is potentially warmer than the surface and atmosphere (Table 5), influenced by geothermal processes [e.g., on Mars (Jones et al., 2011)], thermal convection [e.g., on Enceladus and Titan (Mitri and Showman, 2008)] and radiolysis [e.g., on Mars (Dzaugis et al., 2018)]. Several planetary bodies (Enceladus, Titan, Ceres, and Europa) likely have subsurface oceans, and Mars could potentially have a limited supply of groundwater (Clifford et al., 2010). Potential communities in these extraterrestrial subsurface environments are unlikely to be supported by surface exports of organic carbon like on our planet (Kallmeyer et al., 2012), but rather by in situ production fueled by $\mathrm{H}_{2}$ and abiotic $\mathrm{CH}_{4}$. The abiotic production of $\mathrm{H}_{2}$ can occur through a variety of mechanisms, including the radiolysis of water (Lin et al., 2005; Dzaugis et al., 2018) and serpentinization at both high and low temperatures (Neubeck et al., 2011; McCollom, 2016).

Serpentinization consists of water-rock interactions involving the hydration of $\mathrm{Fe}^{2+}$-rich minerals (primarily olivines), resulting in alkaline $\mathrm{pH}$, production of $\mathrm{H}_{2}$ and potentially lowmolecular weight organic carbon (e.g., formate, methane and a wide variety of other organic compounds) (Schrenk et al., 2013). 
Thus, serpentinization may have played a role in the origins of life on Earth (Russell et al., 2010) and perhaps on icy worlds as well (Russell et al., 2014, 2017). Several planetary bodies could have ongoing serpentinization in a subsurface ocean, including Enceladus, Titan, Ceres, and Europa (Table 5), and serpentinization reactions could be widespread in the cosmos (Holm et al., 2015). Mars might also have serpentinization occurring in the subsurface or had serpentinization occurring millions of years ago, as indicated by the observation of hydrated minerals, such as serpentine phases, on the surface of Mars (Ehlmann et al., 2010). Serpentinite-hosted sites on planetary bodies could likely support chemoautotrophic life, such as methanogens (McCollom, 1999). For example, the piezotolerant thermophile Methanothermococcus okinawensis was capable of growing under Enceladus-like conditions up to $5 \mathrm{MPa}$ (Taubner et al., 2018), and the thermophilic methanogen, Methanothermobacter wolfeii, could survive subsurface Marslike conditions across $\mathrm{pH} 5-9$, pressure $0.1-122 \mathrm{MPa}$, and temperature at $55^{\circ} \mathrm{C}$ (Sinha et al., 2017). The $55^{\circ} \mathrm{C}$ temperature corresponds to a Martian depth of 1-30 km and 10-304 MPa (Sinha et al., 2017).

In contrast to serpentinization, radiolysis consists of radionuclides decay, such as uranium, thorium, and radioactive potassium, decomposing water molecules into oxidizing radicals that then react with oxidizable substrates, such as pyrite, generating the necessary chemical energy for life to survive. For example, the sulfate-reducing bacterium Candidatus Desulforudis audaxviator is the only species observed in fracture fluids at depths $>1.5 \mathrm{~km}$ (Mponeng mine, Johannesburg, South Africa) and is likely influenced by the radiolytic production of such chemical species as $\mathrm{H}_{2}$ and sulfate (Chivian et al., 2008). It is possible that radiolysis could support such life on other planetary bodies, including the Europan ocean (Altair et al., 2018) and the martian subsurface (Michalski et al., 2018).

It is important to note that the presence of liquid water (or other liquid solvent) is the main indicator to consider the possibility of extinct or extant life on a planetary body. Planetary bodies with low water activity $\left(\mathrm{a}_{\mathrm{w}}<0.6\right.$, see section "Salinity and Water Activity") may not have the capability to harbor life. In places with low water activity, desiccationtolerance could become an important factor in determining the survivability of organisms, coupled with the transient availability of water over time (either by precipitation, moisture, fog, or atmospheric humidity). For example, desiccation tolerant organisms may be able to survive under Mars-like surface conditions (Johnson et al., 2011).

While it is possible to use our knowledge of the boundary conditions of Earth's life to map possible habitable environments on other planetary bodies, the discussion regarding the potential for life to originate elsewhere remains more elusive. Given the limited understanding of the processes that have led to life on our planet, discussions regarding the conditions under which life might originate on other planets remains rather speculative (McKay, 2014). As suggested previously (McKay, 2014), we might assume only planets possessing boundary conditions encompassing Earth's biospace (Figure 2) and/or having all fundamental life requirements (e.g., energy source, solvent and building blocks) might be generative for life. An additional point to keep in mind while discussing the origin-and longterm persistence-of life on a planetary body is the necessity of elemental cycling on planetary scales (Jelen et al., 2016), a role often accomplished on our planet by a combination of geological and biological processes on our planet linked by a complex set of feedback processes over time (Chopra and Lineweaver, 2016; Moore et al., 2017).

\section{FUTURE DIRECTIONS AND OUTLOOK}

Extremophiles have pushed our understanding of the boundaries of life in all directions since they were first discovered. As already highlighted by Harrison et al. (2013) and by the data presented in Tables 3, 4, an analysis of cultured extremophiles highlights that the majority of organisms in culture are in fact polyextremophiles. Despite this, there is a fundamental lack of studies addressing the tolerance of microorganisms to multiple extremes (Rothschild and Mancinelli, 2001; Harrison et al., 2013), potentially hindering our understanding of the limits of life. In the past 50 years of extremophile research it has become apparent that the limit of life varies when organisms face cooccurring multiple extremes. For example, the upper limit of life has been raised beyond $100^{\circ} \mathrm{C}$ when high pressure was also present (Stetter, 1982). Future research will need to focus more on the interaction factor between multiple parameters.

While considering the basic requirements of life discussed in the introduction (namely, energy, solvent, and building blocks), it is possible that the true limits of life are actually controlled by practical implications of these requirements. For example, the current theoretical limits of life regarding temperature, pressure, and salinity are directly linked to the water activity or the stability of biological molecules under such conditions (Price and Sowers, 2004). In the search of life's true limits, it is therefore important to consider the effect (and combined effects) of any parameters directly controlling the availability of water, both at the community and subcellular level, and the stability of macromolecules.

The comparative and historical analysis of the limits of Earth's life provides insight into the epistemology of life's boundary research. Despite ongoing scientific investigations of our planet for most of recorded human history, we still find life in unexpected places, and given the number of Earth ecosystems that still need to be explored in detail, we expect the current boundary of life to be pushed even further. Comparing Earth's parameter space with the biospace of Earth's life (Figure 2), one can hypothesize that life might, indeed, have adapted to occupy nearly all available planetary niches, even transiently. Taken together, these observations suggest that the true shape of the terrestrial biosphere remains undefined. Moreover, the astonishing diversity of planetary bodies and exoplanets (Seager, 2013) will most likely expand the combinatorial space of environmental conditions, allowing us to speculate wildly about possible extraterrestrial lifeforms.

While considering the possibility for life to originate and exist on other planetary bodies, it is important to consider 
the variability of Earth local conditions when compared to the planetary mean (Tables 2, 5). The majority of parameters considered in this review are unlikely to be extreme over an entire planet, and local or transient conditions might still support life. An outstanding example are communities present in microbialites in the Atacama Desert, where seasonal water deliquescence on salt grains was sufficient to sustain a productive and diverse community (Davila et al., 2008). Similarly, Recurring Slope Lineae on the surface of Mars (McEwen et al., 2011) are an extraterrestrial example of a transient condition in which the presence of hydrated salts (Ojha et al., 2015) and seasonality suggests a role for water, albeit limited (Dundas et al., 2017). Therefore, it is unlikely that time-limited, coarse-grained observation of any extraterrestrial environment will be enough to definitely rule out the existence of life or conditions within the boundary space of Earth life, at least transiently.

Whether or not other planetary bodies such as Mars, Enceladus, or Europa could or did support life, the search for Earth's life true limits will inform our exploration of space and could provide insight into processes that have led to the origin of life on our planet.

\section{AUTHOR CONTRIBUTIONS}

NM conducted literature search, created figures, and wrote the manuscript. HA, DB, JF-B, SZ, and MW conducted literature search and wrote the manuscript. DG devised the topic, supervised manuscript structure and data collection, conducted literature search, created figures, and wrote the manuscript.

\section{REFERENCES}

Airey, M. W., Mather, T. A., Pyle, D. M., and Ghail, R. C. (2017). The distribution of volcanism in the Beta-Atla-Themis region of Venus: its relationship to rifting and implications for global tectonic regimes. J. Geophys. Res. Planets 122, 1626-1649. doi: 10.1002/2016JE005205

Aislabie, J. M., Chhour, K. L., Saul, D. J., Miyauchi, S., Ayton, J., Paetzold, R. F., et al. (2006). Dominant bacteria in soils of Marble Point and Wright Valley, Victoria Land, Antarctica. Soil Biol. Biochem. 38, 3041-3056. doi: 10.1016/j.soilbio. 2006. 02.018

Alazard, D., Dukan, S., Urios, A., Verhé, F., Bouabida, N., Morel, F., et al. (2003). Desulfovibrio hydrothermalis sp. nov., a novel sulfate-reducing bacterium isolated from hydrothermal vents. Int. J. Syst. Evol. Microbiol. 53, 173-178. doi: 10.1099/ijs.0.02323-0

Alcaide, M., Stogios, P. J., Lafraya, Á., Tchigvintsev, A., Flick, R., Bargiela, R., et al. (2015). Pressure adaptation is linked to thermal adaptation in saltsaturated marine habitats. Environ. Microbiol. 17, 332-345. doi: 10.1111/14622920.12660

Altair, T., De Avellar, M. G. B., Rodrigues, F., and Galante, D. (2018). Microbial habitability of Europa sustained by radioactive sources. Sci. Rep. 8:260. doi: 10.1038/s41598-017-18470-z

Amato, P., Parazols, M., Sancelme, M., Laj, P., Mailhot, G., and Delort, A. M. (2007). Microorganisms isolated from the water phase of tropospheric clouds at the Puy de Dôme: major groups and growth abilities at low temperatures. FEMS Microbiol. Ecol. 59, 242-254. doi: 10.1111/j.1574-6941.2006.00199.x

Amend, J. P., and Shock, E. L. (2001). Energetics of overall metabolic reaction of thermophilic and hyperthermophylic Archaea and Bacteria. FEMS Microbiol. Rev. 25, 175-243. doi: 10.1111/j.1574-6976.2001.tb00576.x

Anitori, R. P. (2012). Extremophiles: Microbiology and Biotechnology. Poole: Caister Academic Press.

\section{FUNDING}

NM was supported by NASA grant NNA13AA92A and by Air Force Office of Scientific Research Grant FA9550-14-1-0114. This work was in part supported by NSF grant MCB 15-17567 and by the "Biology Meets Subduction" grant from the Alfred P. Sloan Foundation and the Deep Carbon Observatory to DG. DG and NM were partially supported by an ELSI Origins Network (EON) research fellowship, which is supported by a grant from the John Templeton Foundation. The opinions expressed in this publication are those of the authors and do not necessarily reflect the views of the John Templeton Foundation. DG was also partially supported a Deep Life Modeling and Visualization Fellowship, which is supported by the Deep Carbon Observatory. DG acknowledges the support of the project ENIGMA (NASA Astrobiology Institute cycle 8) Grant Number 80NSSC18M0093. HA and JF-B were supported by NSF Graduate Research Fellowships. HA, DB, and JF-B were supported by the Center for Dark Energy Biosphere Investigations NSF Award \#0939564 and the NASA Astrobiology Institute Award \#NNA13AA92A. This is C-DEBI Contribution 468 and NAI Contribution \#138.

\section{ACKNOWLEDGMENTS}

We thank Karla Abuyen for insightful discussions on the limitations of life. We thank Patricia Barcala Dominguez for assistance with figure illustration. We acknowledge the support of the Deep Carbon Observatory and C-DEBI (Center for Dark Energy Biosphere Investigations).

Arney, G., Domagal-Goldman, S. D., Meadows, V. S., Wolf, E. T., Schwieterman, E., Charnay, B., et al. (2016). the pale orange dot: the spectrum and habitability of Hazy Archean Earth. Astrobiology 16, 873-899. doi: $10.1089 /$ ast.2015.1422

Aston, J. E., and Peyton, B. M. (2007). Response of Halomonas campisalis to saline stress: changes in growth kinetics, compatible solute production and membrane phospholipid fatty acid composition. FEMS Microbiol. Lett. 274, 196-203. doi: 10.1111/j.1574-6968.2007.00851.x

Babu, P., Chandel, A. K., and Singh, O. V. (2015). Extremophiles and Their Applications in Medical Processes. Berlin: Springer. doi: 10.1007/978-3-31912808-5

Baker, B. J., and Banfield, J. F. (2003). Microbial communities in acid mine drainage. FEMS Microbiol. Ecol. 44, 139-152. doi: 10.1016/S0168-6496(03) 00028-X

Baker-Austin, C., and Dopson, M. (2007). Life in acid: $\mathrm{pH}$ homeostasis in acidophiles. Trends Microbiol. 15, 165-171. doi: 10.1016/j.tim.2007.02.005

Baland, R. M., Tobie, G., Lefèvre, A., and Van Hoolst, T. (2014). Titan's internal structure inferred from its gravity field, shape, and rotation state. Icarus 237, 29-41. doi: 10.1016/j.icarus.2014.04.007

Barbier, B., Chabin, A., Chaput, D., and Brack, A. (1998). Photochemical processing of amino acids in Earth orbit. Planet. Space Sci. 46, 391-398. doi: 10.1016/ S0032-0633(97)00150-5

Bartlett, D. H., Eloe, E. A., and Lauro, F. M. (2007). "Microbial Adaptation to High Pressure," in Physiology and Biochemistry of Extremophiles, eds G. Charles and G. Nicolas (Washington, DC: American Society of Microbiology), 333-348. doi: $10.1128 / 9781555815813 . c h 25$

Basilevsky, A. T., and Head, J. W. (2003). The surface of Venus. Rep. Prog. Phys. 66, 1699-1734. doi: 10.1088/0034-4885/66/10/R04

Becker, K., Langseth, M. G., and Hyndman, R. D. (1984). “5. Temperature measurements in Hole 395A, Leg 78B," in Initial Reports of the Deep Sea Drilling 
Project, eds R. D. Hyndman, M. H. Salisbury et al. (Washington, DC: U.S. Govt. Printing Office), 689-698. doi: 10.2973/dsdp.proc.78b.105.1984

Bertaux, J.-L., Vandaele, A.-C., Korablev, O., Villard, E., Fedorova, A., Fussen, D. et al. (2007). A warm layer in Venus cryosphere and high-altitude measurements of HF, HCl, H2O and HDO. Nature 450, 646-649. doi: 10.1038/ nature 05974

Bertrand, J. C., Brochier-Armanet, C., Gouy, M., and Westall, F. (2015). "For three billion years, microorganisms were the only inhabitants of the earth," in Environmental Microbiology: Fundamentals and Applications, eds J. Bertrand, P. Caumette, P. Lebaron, R. Matheron, P. Normand, and T. Sime Ngando (Dordrecht: Springer), 25-71. doi: 10.1007/978-94-017-9118-2_4

Blum, J. S., Han, S., Lanoil, B., Saltikov, C., Witte, B., Tabita, F. R., et al. (2009). Ecophysiology of "Halarsenatibacter silvermanii" strain SLAS-1 T, gen. nov., sp. nov., a facultative chemoautotrophic arsenate respirer from salt-saturated Searles Lake, California. Appl. Environ. Microbiol. 75, 1950-1960. doi: 10.1128/ AEM.02614-08

Brassé, C., Buch, A., Coll, P., and Raulin, F. (2017). Low-temperature alkaline pH hydrolysis of oxygen-free Titan Tholins: carbonates' Impact. Astrobiology 17, 8-26. doi: 10.1089/ast.2016.1524

Brock, T. D., and Freeze, H. (1969). Thermus aquaticus gen. nov. and sp. nov., a non-sporulating extreme thermophile. J. Bacteriol. 98, 289-297.

Byrne, R. T., Klingele, A. J., Cabot, E. L., Schackwitz, W. S., Martin, J. A., Martin, J., et al. (2014). Evolution of extreme resistance to ionizing radiation via genetic adaptation of DNA repair. eLife 3:e01322. doi: 10.7554/eLife.01322

Caldwell, M. M., Teramura, A. H., and Tevini, M. (1989). The changing solar ultraviolet climate and the ecological consequences for higher plants. Trends Ecol. Evol. 4, 363-367. doi: 10.1016/0169-5347(89)90100-6

Capece, M. C., Clark, E., Saleh, J. K., Halford, D., Heinl, N., Hoskins, S., et al. (2013). "Polyextremophiles and the constraints for terrestrial habitability," in Polyextremophiles. Cellular Origin, Life in Extreme Habitats and Astrobiology, eds J. Seckbach, A. Oren, and H. Stan-Lotter (Dordrecht: Springer).

Cassidy, T. A., Paranicas, C. P., Shirley, J. H., Dalton, J. B., Teolis, B. D., Johnson, R. E., et al. (2013). Magnetospheric ion sputtering and water ice grain size at Europa. Planet. Space Sci. 77, 64-73. doi: 10.1016/j.pss.2012.07.008

Castillo-Rogez, J., Neveu, M., McSween, H. Y., Fu, R. R., Toplis, M. J., and Prettyman, T. (2018). Insights into Ceres's evolution from surface composition. Meteorit. Planet. Sci. 53, 1820-1843. doi: 10.1111/maps.13181

Chan, C. S., Chan, K. G., Ee, R., Hong, K. W., Urbieta, M. S., Donati, E. R., et al. (2017). Effects of physiochemical factors on prokaryotic Biodiversity in Malaysian circumneutral hot springs. Front. Microbiol. 8:1252. doi: 10.3389/ fmicb.2017.01252

Chivian, D., Brodie, E. L., Alm, E. J., Culley, D. E., Dehal, P. S., DeSantis, T. Z., et al. (2008). Environmental genomics reveals a single-species ecosystem deep within earth. Science 322, 275-278. doi: 10.1126/science.1155495

Chopra, A., and Lineweaver, C. H. (2016). The case for a Gaian bottleneck: the biology of habitability. Astrobiology 16, 7-22. doi: 10.1089/ast.2015.1387

Chyba, C., and Phillips, C. (2001). Possible ecosystems and the search for life on Europa. Proc. Natl. Acad. Sci. U.S.A. 98, 801-804. doi: 10.1073/pnas.98.3.801

Clarke, A., Morris, G. J., Fonseca, F., Murray, B. J., Acton, E., and Price, H. C. (2013). A low temperature limit for life on earth. PLoS One 8:e66207. doi: 10.1371/journal.pone.0066207

Clifford, S. M., Lasue, J., Heggy, E., Boisson, J., McGovern, P., and Max, M. D. (2010). Depth of the Martian cryosphere: revised estimates and implications for the existence and detection of subpermafrost groundwater. J. Geophys. Res. 115, E07001. doi: 10.1029/2009JE003462

Cnossen, I., Sanz-Forcada, J., Favata, F., Witasse, O., Zegers, T., and Arnold, N. F. (2007). Habitat of early life: solar X-ray and UV radiation at Earth's surface 4-3.5 billion years ago. J. Geophys. Res. 112:E02008. doi: 10.1029/2006JE002784

Cockell, C. S. (1999). Life on Venus. Planet. Space Sci. 47, 1487-1501. doi: 10.1016/ S0032-0633(99)00036-7

Cockell, C. S., Lee, P., Osinski, G., Horneck, G., and Broady, P. (2002). Impactinduced microbial endolithic habitats. Meteorit. Planet. Sci. 37, 1287-1298. doi: 10.1111/j.1945-5100.2002.tb01029.x

Cockell, C. S., and Raven, J. A. (2007). Ozone and life on the Archaean Earth. Philos. Trans. A Math. Phys. Eng. Sci. 365, 1889-1901. doi: 10.1098/rsta.2007.2049

Cockell, C. S., Schuerger, A. C., Billi, D., Friedmann, E. I., and Panitz, C. (2005). Effects of a simulated martian uv flux on the cyanobacterium, Chroococcidiopsis. Astrobiology 5, 127-140. doi: 10.1089/ast.2005.5.127
Coker, J. A. (2016). Extremophiles and biotechnology: current uses and prospects. F1000Res. 5:F1000 Faculty Rev-396. doi: 10.12688/f1000research.7432.1

Cole, J. K., Peacock, J. P., Dodsworth, J. A., Williams, A. J., Thompson, D. B., Dong, H., et al. (2013). Sediment microbial communities in Great Boiling Spring are controlled by temperature and distinct from water communities. ISME J. 7, 718-729. doi: 10.1038/ismej.2012.157

Colman, D. R., Poudel, S., Hamilton, T. L., Havig, J. R., Selensky, M. J., Shock, E. L., et al. (2018). Geobiological feedbacks and the evolution of thermoacidophiles. ISME J. 12, 225-236. doi: 10.1038/ismej.2017.162

Confalonieri, F., and Sommer, S. (2011). Bacterial and archaeal resistance to ionizing radiation. J. Phys. Conf. Ser. 261:012005. doi: 10.1088/1742-6596/261/ $1 / 012005$

Cordier, D., Garciá-Sánchez, F., Justo-Garciá, D. N., and Liger-Belair, G. (2017). Bubble streams in Titan's seas as a product of liquid $\mathrm{N} 2+\mathrm{CH} 4+\mathrm{C} 2 \mathrm{H} 6$ cryogenic mixture. Nat. Astron. 1:0102. doi: 10.1038/s41550-017-0102

Czop, M., Motyka, J., Sracek, O., and Szuwarzyñski, M. (2011). Geochemistry of the hyperalkaline Gorka pit lake $(\mathrm{pH}>13)$ in the Chrzanow region, southern Poland. Water Air Soil Pollut. 214, 423-434. doi: 10.1007/s11270-0100433-x

Dalmasso, C., Oger, P., Selva, G., Courtine, D., L'Haridon, S., Garlaschelli, A., et al. (2016). Thermococcus piezophilus sp. nov., a novel hyperthermophilic and piezophilic archaeon with a broad pressure range for growth, isolated from a deepest hydrothermal vent at the Mid-Cayman Rise. Syst. Appl. Microbiol. 39, 440-444. doi: 10.1016/j.syapm.2016.08.003

Daly, M. J., Gaidamakova, E. K., Matrosova, V. Y., Vasilenko, A., Zhai, M., Venkateswaran, A., et al. (2004). Accumulation of $\mathrm{Mn}(\mathrm{II})$ in Deinococcus radiodurans facilitates gamma-radiation resistance. Science 306, 1025-1028. doi: 10.1126/science. 1103185

Danovaro, R., Company, J. B., Corinaldesi, C., D’Onghia, G., Galil, B., Gambi, C., et al. (2010). Deep-Sea Biodiversity in the Mediterranean Sea: the known, the unknown, and the unknowable. PLoS One 5:e11832. doi: 10.1371/journal.pone. 0011832

Dartnell, L. R., Desorgher, L., Ward, J. M., and Coates, A. J. (2007). Modelling the surface and subsurface Martian radiation environment: implications for astrobiology. Geophys. Res. Lett. 34, 4-9. doi: 10.1029/2006GL027494

DasSarma, P., and DasSarma, S. (2018). Survival of microbes in Earth's stratosphere. Curr. Opin. Microbiol. 43, 24-30. doi: 10.1016/j.mib.2017.11.002

DasSarma, S., and DasSarma, P. (2017). "Halophiles," in eLS, (Chichester: John Wiley \& Sons), 1-13. doi: 10.1002/9780470015902.a0000394.pub4

Davila, A. F., Gómez-Silva, B., de los Rios, A., Ascaso, C., Olivares, H., McKay, C. P., et al. (2008). Facilitation of endolithic microbial survival in the hyperarid core of the Atacam Desert by mineral deliquescence. J. Geophys. Res. Biogeosci. 113:G1. doi: 10.1029/2007JG000561

de Kok, R., Irwin, P. G. J., Teanby, N. A., Lellouch, E., Bézard, B., Vinatier, S., et al. (2007). Oxygen compounds in Titan's stratosphere as observed by Cassini CIRS. Icarus 186, 354-363. doi: 10.1016/J.ICARUS.2006.09.016

De Vera, J. P., Boettger, U., Noetzel, R., de la, T., Sánchez, F. J., Grunow, D., et al. (2012). Supporting Mars exploration: BIOMEX in Low Earth Orbit and further astrobiological studies on the Moon using Raman and PanCam technology. Planet. Space Sci. 74, 103-110. doi: 10.1016/j.pss.2012.06.010

Delmelle, P., and Bernard, A. (1994). Geochemistry, mineralogy, and chemical modeling of the acid crater lake of Kawah Ijen Volcano, Indonesia. Geochim. Cosmochim. Acta 58, 2445-2460. doi: 10.1016/0016-7037(94)90023-X

Delort, A. M., Vaïtilingom, M., Amato, P., Sancelme, M., Parazols, M., Mailhot, G., et al. (2010). A short overview of the microbial population in clouds: potential roles in atmospheric chemistry and nucleation processes. Atmos. Res. 98, 249-260. doi: 10.1016/j.atmosres.2010.07.004

Deming, J. W. (2007). "Life in ice formations at very cold temperatures," in Physiology and Biochemistry of Extremophiles, eds C. Gerday, and N. Glansdorff (Washington, DC: American Society of Microbiology), 133-144. doi: 10.1128/ 9781555815813.ch10

DeVeaux, L. C., Müller, J. A., Smith, J., Petrisko, J., Wells, D. P., and DasSarma, S. (2007). Extremely radiation-resistant mutants of a halophilic archaeon with increased single-stranded DNA-binding protein (RPA) gene expression. Radiat. Res. 168, 507-514. doi: 10.1667/RR0935.1

Dickson, J. L., Head, J. W., Levy, J. S., and Marchant, D. R. (2013). Don Juan Pond, Antarctica: near-surface CaCl2-brine feeding Earth's most saline lake and implications for Mars. Sci. Rep. 3:1166. doi: 10.1038/srep01166 
Dion, P., Nautiyal, C. S., and Dion, P. (2008). Microbiology of Extreme Soils. Berlin: Springer. doi: 10.1007/978-3-540-74231-9

Dose, K., Bieger-Dose, A., Ernst, B., Feister, U., Gómez-Silva, B., Klein, A., et al. (2001). Survival of microorganisms under the extreme conditions of the Atacama desert. Orig. Life Evol. Biosph. 31, 287-303. doi: 10.1023/A: 1010788829265

Dundas, C. M., McEwen, A. S., Chojnacki, M., Milazzo, M. P., Byrne, S., McElwaine, J. N., et al. (2017). Granular flows at recurring slope lineae on Mars indicate a limited role for liquid water. Nat. Geosci. 10, 903-907. doi: 10.1038/s41561-017-0012-5

Durvasula, R., and Rao, D. V. S. (eds). (2018). "Extremophiles: from Biology to Biotechnology," in Extremophiles (Boca Raton: Taylor \& Francis, a CRC title, part of the Taylor \& Francis imprint, a member of the Taylor \& Francis Group, the academic division of T\&F Informa plc, 2018 (Boca Raton, FL: CRC Press), 1-18. doi: 10.1201/9781315154695-1

Dzaugis, M., Spivack, A. J., and D'Hondt, S. (2018). Radiolytic H2 production in martian environments. Astrobiology 18, 1137-1146. doi: 10.1089/ast.2017.1654

Dzaugis, M. E., Spivack, A. J., Dunlea, A. G., Murray, R. W., and D’Hondt, S. (2016). Radiolytic hydrogen production in the subseafloor basaltic aquifer. Front. Microbiol. 7:76. doi: 10.3389/fmicb.2016.00076

Edwards, K. J., Bond, P. L., Gihring, T. M., and Banfield, J. F. (2000). An Archaeal iron-oxidizing extreme acidophile important in acid mine drainage. Science 287, 1796-1799. doi: 10.1126/science.287.5459.1796

Ehlmann, B. L., Mustard, J. F., and Murchie, S. L. (2010). Geologic setting of serpentine deposits on Mars. Geophys. Res. Lett. 37, 1-5. doi: 10.1029/ 2010GL042596

Ehresmann, B., Burmeister, S., Schweingruber, R. F. W., and Reitz, G. (2011). Influence of higher atmospheric pressure on the Martian radiation environment: implications for possible habitability in the Noachian epoch. J. Geophys. Res. 116, 1-9. doi: 10.1029/2011JA016616

El-Demerdash, M. A., Hegazy, A. K., and Zilay, A. M. (1995). Vegetation-soil relationships in Tihamah coastal plains of Jazan region, Saudi Arabia. J. Arid Environ. 30, 161-174. doi: 10.1016/S0140-1963(05)80067-9

Emeis, K. C., Robertson, A. H. F., and Richter, D. (1996). Proceedings of the Ocean Drilling Program, Initial Reports, 160. College Station, TX: Ocean Drilling Program.

Everroad, R. C., Otaki, H., Matsuura, K., and Haruta, S. (2012). Diversification of bacterial community composition along a temperature gradient at a thermal spring. Microbes Environ. 27, 374-381. doi: 10.1264/jsme2. ME11350

Fairén, A. G., Davila, A. F., Gago-Duport, L., Amils, R., and McKay, C. P. (2009). Stability against freezing of aqueous solutions on early Mars. Nature 459, 401-404. doi: 10.1038/nature07978

Fairén, A. G., Fernández-Remolar, D., Dohm, J. M., Baker, V. R., and Amils, R. (2004). Inhibition of carbonate synthesis in acidic oceans on early Mars. Nature 431, 423-426. doi: 10.1038/nature02911

Fajardo-Cavazos, P., Morrison, M. D., Miller, K. M., Schuerger, A. C., and Nicholson, W. L. (2018). Transcriptomic responses of Serratia liquefaciens cells grown under simulated Martian conditions of low temperature, low pressure, and CO2-enriched anoxic atmosphere. Sci. Rep. 8:14938. doi: 10.1038/s41598018-33140-4

Fanale, F. P., and Salvail, J. R. (1989). The water regime of asteroid (1) Ceres. Icarus 82, 97-110. doi: 10.1016/0019-1035(89)90026-2

Fang, J., Zhang, L., and Bazylinski, D. A. (2010). Deep-sea piezosphere and piezophiles: geomicrobiology and biogeochemistry. Trends Microbiol. 18, 413422. doi: 10.1016/j.tim.2010.06.006

Fernández-Calviño, D., and Bååth, E. (2010). Growth response of the bacterial community to $\mathrm{pH}$ in soils differing in pH. FEMS Microbiol. Ecol. 73, 149-156. doi: 10.1111/j.1574-6941.2010.00873.x

Ferrera, I., and Reysenbach, A.-L. (2007). "Thermophiles," in Encyclopedia of Life Sciences, (Hoboken, NJ: John Wiley \& Sons), doi: 10.1002/9780470015902. a0000406

Feyhl-Buska, J., Chen, Y., Jia, C., Wang, J. X., Zhang, C. L., and Boyd, E. S. (2016). Influence of growth phase, $\mathrm{pH}$, and temperature on the abundance and composition of tetraether lipids in the thermoacidophile Picrophilus torridus. Front. Microbiol. 7:1323. doi: 10.3389/fmicb.2016.01323

Finlayson, C. M., Milton, R., Prentice, C., and Davidson, N. C. (eds) (2018). The Wetland Book II, Distribution, Description, and Conservation. Berlin: Springer.
Flores, G. E., Shakya, M., Meneghin, J., Yang, Z. K., Seewald, J. S., Geoff Wheat, C., et al. (2012). Inter-field variability in the microbial communities of hydrothermal vent deposits from a back-arc basin. Geobiology 10, 333-346. doi: 10.1111/j.1472-4669.2012.00325.x

Fouke, B. W. (2011). Hot-spring Systems Geobiology: abiotic and biotic influences on travertine formation at Mammoth Hot Springs, Yellowstone National Park, USA. Sedimentology 58, 170-219. doi: 10.1111/j.1365-3091.2010.01209.x

Frank, Y. A., Kadnikov, V. V., Gavrilov, S. N., Banks, D., Gerasimchuk, A. L., Podosokorskaya, O. A., et al. (2016). Stable and variable parts of microbial community in Siberian deep subsurface thermal aquifer system revealed in a long-term monitoring study. Front. Microbiol. 7:2101. doi: 10.3389/fmicb.2016. 02101

Fredrickson, J. K., Li, S. M. W., Gaidamakova, E. K., Matrosova, V. Y., Zhai, M., Sulloway, H. M., et al. (2008). Protein oxidation: key to bacterial desiccation resistance? ISME J. 2, 393-403. doi: 10.1038/ismej.2007.116

Fredrickson, J. K., Zachara, J. M., Balkwill, D. L., Kennedy, D., Li, S. M. W., Kostandarithes, H. M., et al. (2004). Geomicrobiology of high-level nuclear waste-contaminated vadose sediments at the Hanford Site Washington State. Appl. Environ. Microbiol. 70, 4230-4241. doi: 10.1128/AEM.70.7.4230-4241. 2004

Frösler, J., Panitz, C., Wingender, J., Flemming, H.-C., and Rettberg, P. (2017). Survival of Deinococcus geothermalis in Biofilms under Desiccation and Simulated Space and Martian Conditions. Astrobiology 17, 431-447. doi: 10. 1089/ast.2015.1431

Fulchignoni, M., Ferri, F., Angrilli, F., Ball, A. J., Bar-Nun, A., Barucci, M. A., et al. (2005). In situ measurements of the physical characteristics of Titan's environment. Nature 438, 785-791. doi: 10.1038/nature04314

Gioia, G., Chakraborty, P., Marshak, S., and Kieffer, S. W. (2007). Unified model of tectonics and heat transport in a frigid Enceladus. Proc. Natl. Acad. Sci. U.S.A. 104, 13578-13581. doi: 10.1073/pnas.0706018104

Giovannelli, D., D’Errico, G., Manini, E., Yakimov, M., and Vetriani, C. (2013). Diversity and phylogenetic analyses of bacteria from a shallow-water hydrothermal vent in Milos island (Greece). Front. Microbiol. 4:184. doi: 10. 3389/fmicb.2013.00184

Glein, C. R., Baross, J. A., and Waite, J. H. (2015). The pH of Enceladus' ocean. Geochim. Cosmochim. Acta 162, 202-219. doi: 10.1016/j.gca.2015.04.017

Grindrod, P. M., Fortes, A. D., Nimmo, F., Feltham, D. L., Brodholt, J. P., and Voèadlo, L. (2008). The long-term stability of a possible aqueous ammonium sulfate ocean inside Titan. Icarus 197, 137-151. doi: 10.1016/j.icarus.2008. 04.006

Hallsworth, J. E., Yakimov, M. M., Golyshin, P. N., Gillion, J. L. M., D’Auria, G., De Lima Alves, F., et al. (2007). Limits of life in $\mathrm{MgCl} 2$-containing environments: chaotropicity defines the window. Environ. Microbiol. 9, 801-813. doi: 10.1111/ j.1462-2920.2006.01212.x

Hand, K. P., and Carlson, R. W. (2015). Europa's surface color suggests an ocean rich with sodium chloride. Geophys. Res. Lett. 42, 3174-3178. doi: 10.1002/ 2015GL063559

Hans Wedepohl, K. (1995). The composition of the continental crust. Geochim. Cosmochim. Acta 59, 1217-1232. doi: 10.1016/0016-7037(95)00038-2

Hansen, A. A., Jensen, L. L., Kristoffersen, T., Mikkelsen, K., Merrison, J., Finster, K. W., et al. (2009). Effects of long-term simulated Martian conditions on a freeze-dried and homogenized bacterial permafrost community. Astrobiology 9 , 229-240. doi: 10.1089/ast.2008.0244

Harrison, J. P., Gheeraert, N., Tsigelnitskiy, D., and Cockell, C. S. (2013). The limits for life under multiple extremes. Trends Microbiol. 21, 204-212. doi: 10.1016/j.tim.2013.01.006

Hassler, D. M., Zeitlin, C., Wimmer-schweingruber, R. F., Ehresmann, B., Rafkin, S., Eigenbrode, J. L., et al. (2014). Mars' surface radiation environment. Science 343:1244797. doi: 10.1126/science.1244797

Hayne, P. O., and Aharonson, O. (2015). Thermal stability of ice on Ceres with rough topography. J. Geophys. Res. E Planets 120, 1567-1584. doi: 10.1002/ 2015JE004887

Hecht, M. H., Kounaves, S. P., Quinn, R. C., West, S. J., Young, S. M. M., Ming, D. W., et al. (2009). Detection of perchlorate and the soluble chemistry of Martian soil at the phoenix lander site. Science 325, 64-67. doi: 10.1126/science. 1172466

Hendrix, A. R., Vilas, F., and Li, J. Y. (2016). Ceres: sulfur deposits and graphitized carbon. Geophys. Res. Lett. 43, 8920-8927. doi: 10.1002/2016GL070240 
Hoehler, T. M., and Jørgensen, B. B. (2013). Microbial life under extreme energy limitation. Nat. Rev. Microbiol. 11, 83-94. doi: 10.1038/nrmicro2939

Holm, D. A., Owen, L., and Ochsenwald, W. L. (2017). Arabian Desert. Available at: https://www.britannica.com/place/Arabian-Desert

Holm, N. G., Oze, C., Mousis, O., Waite, J. H., and Guilbert-Lepoutre, A. (2015). Serpentinization and the Formation of $\mathrm{H} 2$ and $\mathrm{CH} 4$ on Celestial Bodies (Planets, Moons, Comets). Astrobiology 15, 587-600. doi: 10.1089/ast.2014.1188

Horneck, G., Klaus, D. M., and Mancinelli, R. L. (2010). Space microbiology. Microbiol. Mol. Biol. Rev. 74, 121-156. doi: 10.1128/MMBR.00016-09

Hsu, H. W., Postberg, F., Sekine, Y., Shibuya, T., Kempf, S., Horányi, M., et al. (2015). Ongoing hydrothermal activities within Enceladus. Nature 519, 207-210. doi: 10.1038/nature14262

Hug, L. A., Baker, B. J., Anantharaman, K., Brown, C. T., Probst, A. J., Castelle, C. J., et al. (2016). A new view of the tree of life. Nat. Microbiol. 1:16048. doi: $10.1038 / \mathrm{nmicrobiol} .2016 .48$

Jaakkola, S. T., Ravantti, J. J., Oksanen, H. M., and Bamford, D. H. (2016). Buried alive: microbes from ancient halite. Trends Microbiol. 24, 148-160. doi: 10.1016/ j.tim.2015.12.002

James, J. J., Tiller, R. L., and Richards, J. H. (2005). Multiple resources limit plant growth and function in a saline-alkaline desert community. J. Ecol. 93, 113-126. doi: 10.1111/j.0022-0477.2004.00948.x

Javor, B. (1984). Growth potential of halophilic bacteria isolated from solar salt environments: carbon sources and salt requirements. Appl. Environ. Microbiol. $48,352-360$

Jebbar, M., Franzetti, B., Girard, E., and Oger, P. (2015). Microbial diversity and adaptation to high hydrostatic pressure in deep-sea hydrothermal vents prokaryotes. Extremophiles 19, 721-740. doi: 10.1007/s00792-015-0760-3

Jelen, B. I., Giovannelli, D., and Falkowski, P. G. (2016). The role of microbial electron transfer in the coevolution of the biosphere and geosphere. Annu. Rev. Microbiol. 70, 45-62. doi: 10.1146/annurev-micro-102215-095521

Jennings, D. E., Cottini, V., Nixon, C. A., Achterberg, R. K., Flasar, F. M., Kunde, V. G., et al. (2016). Surface temperatures on Titan during northern winter and spring. Astrophys. J. 816:L17. doi: 10.3847/2041-8205/816/1/L17

Jin, Q., and Kirk, M. F. (2018). pH as a primary control in environmental microbiology: 1. Thermodynamic Perspective. Front. Environ. Sci. 6:21. doi: 10.3389/fenvs.2018.00021

Johnson, A. P., Pratt, L. M., Vishnivetskaya, T., Pfiffner, S., Bryan, R. A., Dadachova, E., et al. (2011). Extended survival of several organisms and amino acids under simulated martian surface conditions. Icarus 211, 1162-1178. doi: 10.1016/j.icarus.2010.11.011

Jolivet, E., L'Haridon, S., Corre, E., Forterre, P., and Prieur, D. (2003). Thermococcus gammatolerans sp. nov., a hyperthermophilic archeon from a deep-sea hydrothermal vent that resists ionizing radiation. Int. J. Syst. Evol. Microbiol. 53, 847-851. doi: 10.1099/ijs.0.02503-0

Jones, B. F., Eugster, H. P., and Rettig, S. L. (1977). Hydrochemistry of the Lake Magadi basin, Kenya. Geochim. Cosmochim. Acta 41, 53-72. doi: 10.1016/00167037(77)90186-7

Jones, E. G., Lineweaver, C. H., and Clarke, J. D. (2011). An extensive phase space for the potential martian biosphere. Astrobiology 11, 1017-1033. doi: 10.1089/ ast. 2011.0660

Jones, R. M., Goordial, J. M., and Orcutt, B. N. (2018). Low energy subsurface environments as extraterrestrial analogs. Front. Microbiol. 9:1605. doi: 10.3389/ fmicb.2018.01605

Junge, K., Eicken, H., and Deming, J. W. (2004). Bacterial Activity at -2 to $20^{\circ} \mathrm{C}$ in Arctic Wintertime Sea Ice. Appl. Environ. Microbiol. 70, 550-557. doi: 10.1128/AEM.70.1.550-557.2004

Kallmeyer, J., Pockalny, R., Adhikari, R. R., Smith, D. C., and D'Hondt, S. (2012). Global distribution of microbial abundance and biomass in subseafloor sediment. Proc. Natl. Acad. Sci. U.S.A. 109, 16213-16216. doi: 10.1073/pnas. 1203849109

Karbe, L. (1986). "Hot Brines and the Deep Sea Environment," in Red Sea, eds A. J. Edwards and S. M. Head (Oxford: Pergamon Press).

Kargel, J. S., Kaye, J. Z., Head, J. W., Marion, G. M., Sassen, R., Crowley, J. K., et al. (2000). Europa's crust and ocean: origin, composition, and the prospects for life. Icarus 148, 226-265. doi: 10.1006/ICAR.2000.6471

Kashefi, K., Holmes, D. E., Reysenbach, A. L., and Lovley, D. R. (2002). Use of $\mathrm{Fe}$ (III) as an electron acceptor to recover previously uncultured hyperthermophiles: Isolation and characterization of Geothermobacterium ferrireducens gen. nov., sp. nov. Appl. Environ. Microbiol. 68, 1735-1742. doi: 10.1128/AEM.68.4.1735-1742.2002

Kashefi, K., and Lovley, D. R. (2003). Extending the upper temperature limit for life. Science 301:934. doi: 10.1126/science.1086823

Kattenhorn, S. A., and Prockter, L. M. (2014). Evidence for subduction in the ice shell of Europa. Nat. Geosci. 7, 762-767. doi: 10.1038/ngeo2245

Kavak, M. T., and Karadogan, S. (2012). Investigation of Sea Surface Temperature Variation of Lake Van Using AVHRR. https://www.researchgate.net/publication/ 256512293_INVESTIGATION_SEA_SURFACE_TEMPERATURE_ VARIATION_OF_LAKE_VAN_USING_AVHRR

Kelly, D. P., and Wood, A. P. (2000). Reclassification of some species of Thiobacillus Acidithiobacillus gen. nov., Halothiobacillus. Int. J. Syst. Evol. Microbiol. 50, 511-516. doi: 10.1099/00207713-50-2-511

Kimura, J., and Kitadai, N. (2015). Polymerization of building blocks of life on Europa and other icy moons. Astrobiology 15, 430-441. doi: 10.1089/ast.2015. 1306

Kingsbury, J. M. (1954). On the Isolation, Physiology, and Development of a Minute, Hardy, Bluegreen Alga. Ph.D. thesis, Dr. Diss. Harvard Univ.

Knoll, A. H. (2015). Life on a Young Planet: The First Three Billion Years of Evolution on Earth. Princeton, NJ: Princeton University Press. doi: 10.1515/ 9781400866045

Konn, C., Charlou, J. L., Donval, J. P., Holm, N. G., Dehairs, F., and Bouillon, S (2009). Hydrocarbons and oxidized organic compounds in hydrothermal fluids from Rainbow and Lost City ultramafic-hosted vents. Chem. Geol. 258, 299-314. doi: 10.1016/J.CHEMGEO.2008.10.034

Koschinsky, A., Garbe-Schönberg, D., Sander, S., Schmidt, K., Gennerich, H. H., and Strauss, H. (2008). Hydrothermal venting at pressure-temperature conditions above the critical point of seawater, $5^{\circ} \mathrm{S}$ on the Mid-Atlantic Ridge. Geology 36, 615-618. doi: 10.1130/G24726A.1

Kottemann, M., Kish, A., Iloanusi, C., Bjork, S., and DiRuggiero, J. (2005). Physiological responses of the halophilic archaeon Halobacterium sp. strain NRC1 to desiccation and gamma irradiation. Extremophiles 9, 219-227. doi: 10.1007/s00792-005-0437-4

Krisko, A., and Radman, M. (2013). Biology of extreme radiation resistance: the way of Deinococcus radiodurans. Cold Spring Harb. Perspect. Biol. 5:a012765. doi: $10.1101 /$ cshperspect.a012765

Krulwich, T. A., Sachs, G., and Padan, E. (2011). Molecular aspects of bacterial pH sensing and homeostasis. Nat. Rev. Microbiol. 9, 330-343. doi: 10.1038/ nrmicro2549

Kuang, J.-L., Huang, L.-N., Chen, L.-X., Hua, Z.-S., Li, S.-J., Hu, M., et al. (2013). Contemporary environmental variation determines microbial diversity patterns in acid mine drainage. ISME J. 7, 1038-1050. doi: 10.1038/ismej.2012.139

Küppers, M., O’Rourke, L., Bockelée-Morvan, D., Zakharov, V., Lee, S., Von Allmen, P., et al. (2014). Localized sources of water vapour on the dwarf planet (1) Ceres. Nature 505, 525-527. doi: 10.1038/nature12918

La Duc, M. T., Benardini, J. N., Kempf, M. J., Newcombe, D. A., Lubarsky, M., and Venkateswaran, K. (2007). Microbial diversity of Indian ocean hydrothermal vent plumes: microbes tolerant of desiccation. Peroxide Exposure, and Ultraviolet and $\gamma$-Irradiation. Astrobiology 7, 416-431. doi: 10.1089/ast.2006. 0060

Lammer, H., Bredehöft, J. H., Coustenis, A., Khodachenko, M. L., Kaltenegger, L., Grasset, O., et al. (2009). What makes a planet habitable? Astron. Astrophys. Rev. 17, 181-249. doi: 10.1007/s00159-009-0019-z

Lane, N., Allen, J. F., and Martin, W. (2010). How did LUCA make a living? Chemiosmosis in the origin of life - Lane - 2010 - BioEssays - Wiley Online Library. BioEssays 32, 271-280. doi: 10.1002/bies.200900131

Lane, N., and Martin, W. F. (2012). The origin of membrane bioenergetics. Cell 151, 1406-1416. doi: 10.1016/j.cell.2012.11.050

Lang, N. P., and Hansen, V. L. (2006). Venusian channel formation as a subsurface process. J. Geophys. Res. E Planets 111:E04001. doi: 10.1029/2005JE 002629

Langmuir, D. (1971). The geochemistry of some carbonate ground waters in central Pennsylvania. Geochim. Cosmochim. Acta 35, 1023-1045. doi: 10.1016/00167037(71)90019-6

LaRowe, D. E., and Amend, J. P. (2015). Power limits for microbial life. Front. Microbiol. 6:718. doi: 10.3389/fmicb.2015.00718

Lauber, C. L., Hamady, M., Knight, R., and Fierer, N. (2009). Pyrosequencing-based assessment of soil $\mathrm{pH}$ as a predictor of soil bacterial community structure at the 
continental scale. Appl. Environ. Microbiol. 75, 5111-5120. doi: 10.1128/AEM. 00335-09

Lechmann, S. M., Schmalholz, S. M., Hetényi, G., May, D. A., and Kaus, B. J. P. (2014). Quantifying the impact of mechanical layering and underthrusting on the dynamics of the modern India-Asia collisional system with 3-D numerical models. J. Geophys. Res. Solid Earth 119, 616-644. doi: 10.1002/2012JB009748

Li, H., Yang, Q., Li, J., Gao, H., Li, P., and Zhou, H. (2015). The impact of temperature on microbial diversity and AOA activity in the Tengchong Geothermal Field, China. Sci. Rep. 5:17056. doi: 10.1038/srep17056

Lin, L. H., Hall, J., Lippmann-Pipke, J., Ward, J. A., Lollar, B. S., DeFlaun, M., et al. (2005). Radiolytic H2 in continental crust: nuclear power for deep subsurface microbial communities. Geochem. Geophys. Geosyst. 6:Q07003. doi: 10.1029/ 2004GC000907

Lloyd, K. G., Steen, A. D., Ladau, J., Yin, J., and Crosby, L. (2018). Phylogenetically novel uncultured microbial cells dominate earth microbiomes. mSystems 3:e00185-18. doi: 10.1128/mSystems.00055-18

Longstaff, A. (2014). Astrobiology: An Introduction. Boca Raton, FL: CRC Press. doi: $10.1201 / \mathrm{b} 17880$

Lozupone, C. A., and Knight, R. (2007). Global patterns in bacterial diversity. Proc. Natl. Acad. Sci. U.S.A. 104, 11436-11440. doi: 10.1073/pnas.0611525104

Lu, J., Nogi, Y., and Takami, H. (2001). Oceanobacillus iheyensis gen. nov., sp. nov., a deep-sea extremely halotolerant and alkaliphilic species isolated from a depth of $1050 \mathrm{~m}$ on the Iheya Ridge. FEMS Microbiol. Lett. 205, 291-297. doi: 10.1016/S0378-1097(01)00493-1

Magnabosco, C., Lin, L. H., Dong, H., Bomberg, M., Ghiorse, W., Stan-Lotter, H., et al. (2018). The biomass and biodiversity of the continental subsurface. Nat. Geosci. 11, 707-717. doi: 10.1038/s41561-018-0221-6

Mancinelli, R. L., and Klovstad, M. (2000). Martian soil and UV radiation: Microbial viability assessment on spacecraft surfaces. Planet. Space Sci. 48, 1093-1097. doi: 10.1016/S0032-0633(00)00083-0

Mantyla, A. W., and Reid, J. L. (1983). Abyssal characteristics of the World Ocean waters. Deep Sea Res. Part A Oceanogr. Res. Pap. 30, 805-833. doi: 10.1016/01980149(83)90002-X

Mapelli, F., Barozzi, A., Michoud, G., Merlino, G., Crotti, E., Borin, S., et al. (2017). "An updated view of the microbial diversity in deep hypersaline anoxic basins," in Adaption of Microbial Life to Environmental Extremes, 2nd Edn, eds H. StanLotter, and S. Fendrihan (Cham: Springer), 23-40. doi: 10.1007/978-3-31948327-6_2

Marion, G. M., Kargel, J. S., Catling, D. C., and Jakubowski, S. D. (2005). Effects of pressure on aqueous chemical equilibria at subzero temperatures with applications to Europa. Geochim. Cosmochim. Acta 69, 259-274. doi: 10.1016/j. gca.2004.06.024

Martin, A., and McMinn, A. (2018). Sea ice, extremophiles and life on extra-terrestrial ocean worlds. Int. J. Astrobiol. 17, 1-16. doi: 10.1017/ S1473550416000483

Mastrogiuseppe, M., Poggiali, V., Hayes, A., Lorenz, R., Lunine, J., Picardi, G., et al. (2014). The bathymetry of a Titan sea. Geophys. Res. Lett. 41, 1432-1437. doi: $10.1002 / 2013 \mathrm{GL} 058618$

McCollom, T. M. (1999). Methanogenesis as a potential source of chemical energy for primary biomass production by autotrophic organisms in hydrothermal systems on Europa. J. Geophys. Res. Planets 104, 30729-30742. doi: 10.1029/ 1999JE001126

McCollom, T. M. (2016). Abiotic methane formation during experimental serpentinization of olivine. Proc. Natl. Acad. Sci. U.S.A. 113, 13965-13970. doi: $10.1073 /$ pnas. 1611843113

McCord, T. B., and Castillo-Rogez, J. C. (2018). Ceres's internal evolution: The view after Dawn. Meteorit. Planet. Sci. 53, 1778-1792. doi: 10.1111/maps.13135

McCord, T. B., and Sotin, C. (2005). Ceres: evolution and current state. J. Geophys. Res. E Planets 110:E5. doi: 10.1029/2004JE002244

McCord, T. B., and Zambon, F. (2019). The surface composition of Ceres from the Dawn mission. Icarus 318, 2-13. doi: 10.1016/j.icarus.2018. 03.004

McDermott, J. M., Sylva, S. P., Ono, S., German, C. R., and Seewald, J. S. (2018). Geochemistry of fluids from Earth's deepest ridge-crest hot-springs: piccard hydrothermal field, Mid-Cayman Rise. Geochim. Cosmochim. Acta 228, 95-118. doi: 10.1016/j.gca.2018.01.021

McDonough, W. F., and Sun, S. S. (1995). The composition of the Earth. Chem. Geol. 120, 223-253. doi: 10.1016/0009-2541(94)00140-4
McEwen, A. S., Ojha, L., Dundas, C. M., Mattson, S. S., Byrne, S., Wray, J. J., et al. (2011). Seasonal flows on warm Martian slopes. Science 333, 740-743. doi: $10.1126 /$ science. 1204816

McGrath, M. A., Hansen, C. J., and Hendrix, A. R. (2009). "Observations of Europa's Tenuous Atmosphere," in Europa, R. T. Pappalardo, W. B. McKinnon, and K. K. Khurana (Tucson, AZ: University of Arizona Press), 485-506.

McKay, C. P. (2014). Requirements and limits for life in the context of exoplanets. Proc. Natl. Acad. Sci. U.S.A. 111, 12628-12633. doi: 10.1073/pnas.1304212111

McKay, C. P. (2016). Titan as the Abode of Life. Life 6:8. doi: 10.3390/life6010008

Meklat, A., Bouras, N., Zitouni, A., Mathieu, F., Lebrihi, A., Schumann, P., et al. (2013). Actinopolyspora mzabensis sp. nov., a halophilic actinomycete isolated from an Algerian Saharan soil. Int. J. Syst. Evol. Microbiol. 63, 3787-3792. doi: 10.1099/ijs.0.046649-0

Méndez-García, C. C., Pelaez, A. I., Mesa, V., Sanchez, J., Golyshina, O. V., and Ferrer, M. (2015). Microbial diversity and metabolic networks in acid mine drainage habitats. Front. Microbiol 6:475. doi: 10.3389/fmicb.2015.00475

Merlino, G., Barozzi, A., Michoud, G., Ngugi, D. K., and Daffonchio, D. (2018). Microbial ecology of deep-sea hypersaline anoxic basins. FEMS Microbiol. Ecol. 94, doi: $10.1093 /$ femsec/fiy085

Mesbah, N., and Wiegel, J. (2005). "Halophilic thermophiles: a novel group of extremophiles," in Microbial Diversity: Current Perspective and Potential Applications, eds T. Satyanarayana, and B. N. Johri (New Delhi: International Publishing House Pvt. Ltd.), 91-118 doi: 10.1196/annals.1419.028

Michalski, J. R., Cuadros, J., Niles, P. B., Parnell, J., Deanne Rogers, A., and Wright, S. P. (2013). Groundwater activity on Mars and implications for a deep biosphere. Nat. Geosci. 6, 133-138. doi: 10.1038/ngeo1706

Michalski, J. R., Onstott, T. C., Mojzsis, S. J., Mustard, J., Chan, Q. H. S., Niles, P. B., et al. (2018). The Martian subsurface as a potential window into the origin of life. Nat. Geosci. 11:21. doi: 10.1038/s41561-017-0015-2

Michiels, C., Bartlett, D. H., and Aersten, A. (eds) (2008). High-Pressure Microbiology. Washington, DC: American Society of Microbiology. doi: 10. 1128/9781555815646

Miettinen, H., Kietäväinen, R., Sohlberg, E., Numminen, M., Ahonen, L., and Itävaara, M. (2015). Microbiome composition and geochemical characteristics of deep subsurface high-pressure environment, Pyhäsalmi mine Finland. Front. Microbiol. 6:1203. doi: 10.3389/fmicb.2015.01203

Mildrexler, D. J., Zhao, M., and Running, S. W. (2011). Satellite finds highest land skin temperatures on Earth. Bull. Am. Meteorol. Soc. 92, 855-860. doi: 10.1175/2011BAMS3067.1

Miller, S. R., Strong, A. L., Jones, K. L., and Ungerer, M. C. (2009). Barcoded pyrosequencing reveals shared bacterial community properties along the temperature gradients of two alkaline hot springs in Yellowstone National Park. Appl. Environ. Microbiol. 75, 4565-4572. doi: 10.1128/AEM.02792-08

Millero, F. J., and Rabindra, N. R. (1997). A chemical equilibrium model for the carbonate system in natural waters. Croat. Chem. Acta 70, 1-38.

Mitchell, J. L., and Lora, J. M. (2016). The climate of titan. Annu. Rev. Earth Planet. Sci. 44, 353-380. doi: 10.1146/annurev- earth-060115-012428

Mitri, G., Meriggiola, R., Hayes, A., Lefevre, A., Tobie, G., Genova, A., et al. (2014). Shape, topography, gravity anomalies and tidal deformation of Titan. Icarus 236, 169-177. doi: 10.1016/j.icarus.2014.03.018

Mitri, G., and Showman, A. P. (2008). Thermal convection in ice-I shells of Titan and Enceladus. Icarus 193, 387-396. doi: 10.1016/j.icarus.2007. 07.016

Mojib, N., Farhoomand, A., Andersen, D. T., and Bej, A. K. (2013). UV and cold tolerance of a pigment-producing Antarctic Janthinobacterium sp, Ant5-2. Extremophiles 17, 367-378. doi: 10.1007/s00792-013-0525-9

Moore, E. K., Jelen, B. I., Giovannelli, D., Raanan, H., and Falkowski, P. G. (2017). Metal availability and the expanding network of microbial metabolisms in the Archaean eon. Nat. Geosci. 10, 629-636. doi: 10.1038/ngeo3006

Mormile, M. R., Romine, M. F., Garcia, M. T., Ventosa, A., Bailey, T. J., and Peyton, B. M. (1999). Halomonas campisalis sp, nov., a denitrifying, moderately haloalkaliphilic bacterium. Syst. Appl. Microbiol. 22, 551-558. doi: 10.1016/ S0723-2020(99)80008-3

Morris, S., and Taylor, A. C. (1983). Diurnal and seasonal variation in physicochemical conditions within intertidal rock pools. Estuar. Coast. Shelf Sci. 17, 339-355. doi: 10.1016/0272-7714(83)90026-4

Mottl, M. J., Komor, S. C., Fryer, P., and Moyer, C. L. (2003). Deep-slab fluids fuel extremophilic Archaea on a Mariana forearc serpentinite mud volcano: 
ocean drilling program leg 195. Geochem. Geophys. Geosyst. 4:GC00588. doi: 10.1029/2003GC000588

Mottl, M. J., Wheat, C. G., Fryer, P., Gharib, J., and Martin, J. B. (2004). Chemistry of springs across the Mariana forearc shows progressive devolatilization of the subducting plate. Geochim. Cosmochim. Acta 68, 4915-4933. doi: 10.1016/j.gca. 2004.05.037

Muñoz-Iglesias, V., Bonales, L. J., and Prieto-Ballesteros, O. (2013). pH and Salinity Evolution of Europa's Brines: Raman Spectroscopy Study of Fractional Precipitation at 1 and 300 Bar. Astrobiology 13, 693-702. doi: 10.1089/ast.2012. 0900

Mykytczuk, N. C. S., Foote, S. J., Omelon, C. R., Southam, G., Greer, C. W., and Whyte, L. G. (2013). Bacterial growth at $-15^{\circ} \mathrm{C}$; molecular insights from the permafrost bacterium Planococcus halocryophilus Or1. ISME J. 7, 1211-1226. doi: 10.1038/ismej.2013.8

Mykytczuk, N. C. S., Wilhelm, R. C., and Whyte, L. G. (2012). Planococcus halocryophilus sp. nov., an extreme sub-zero species from high arctic permafrost. Int. J. Syst. Evol. Microbiol. 62, 1937-1944. doi: 10.1099/ijs.0. 035782-0

Namsaraev, Z. B., Gorlenko, V. M., Namsaraev, B. B., Buryukhaev, S. P., and Yurkov, V. V. (2003). The structure and biogeochemical activity of the phototrophic communities from the bol'sherechenskii alkaline hot spring. Microbiology 72, 193-202. doi: 10.1023/A:1023272131859

NASA (2018). Mars Fact Sheet. Greenbelt, MD: NASA. Available at: https://nssdc. gsfc.nasa.gov/planetary/factsheet/marsfact.html (accessed September 27, 2018).

Neubeck, A., Duc, N. T., Bastviken, D., Crill, P., and Holm, N. G. (2011). Formation of $\mathrm{H} 2$ and $\mathrm{CH} 4$ by weathering of olivine at temperatures between 30 and $70^{\circ} \mathrm{C}$. Geochem. Trans. 12:6. doi: 10.1186/1467-4866-12-6

Nevarez, L., Vasseur, V., Le Madec, A., Le Bras, M. A., Coroller, L., Leguérinel, I., et al. (2009). Physiological traits of Penicillium glabrum strain LCP 08.5568, a filamentous fungus isolated from bottled aromatised mineral water. Int. J. Food Microbiol. 130, 166-171. doi: 10.1016/j.ijfoodmicro.2009.01.013

Neveu, M., and Desch, S. J. (2015). Geochemistry, thermal evolution, and cryovolcanism on Ceres with a muddy ice mantle. Geophys. Res. Lett. 42, 10197-10206. doi: 10.1002/2015GL066375

Nicholson, W. L., Krivushin, K., Gilichinsky, D., and Schuerger, A. C. (2013). Growth of Carnobacterium spp. from permafrost under low pressure, temperature, and anoxic atmosphere has implications for Earth microbes on Mars. Proc. Natl. Acad. Sci. U.S.A. 110, 666-671. doi: 10.1073/pnas.12097 93110

Nicholson, W. L., and Schuerger, A. C. (2005). Bacillus subtilis spore survival and expression of germination-induced bioluminescence after prolonged incubation under simulated mars atmospheric pressure and composition: implications for planetary protection and Lithopanspermia. Astrobiology 5, 536-544. doi: 10.1089/ast.2005.5.536

Noack, L., Höning, D., Rivoldini, A., Heistracher, C., Zimov, N., Journaux, B., et al. (2016). Water-rich planets: How habitable is a water layer deeper than on Earth? Icarus 277, 215-236. doi: 10.1016/j.icarus.2016.05.009

Noell, A. C., Ely, T., Bolser, D. K., Darrach, H., Hodyss, R., Johnson, P. V., et al. (2015). Spectroscopy and Viability of Bacillus subtilis Spores after Ultraviolet Irradiation: Implications for the Detection of Potential Bacterial Life on Europa. Astrobiology 15, 20-31. doi: 10.1089/ast.2014.1169

Nogi, Y., Hosoya, S., Kato, C., and Horikoshi, K. (2004). Colwellia piezophila sp. nov., a novel piezophilic species from deep-sea sediments of the Japan Trench. Int. J. Syst. Evol. Microbiol. 54, 1627-1631. doi: 10.1099/ijs.0. 03049-0

Nordheim, T. A., Hand, K. P., and Paranicas, C. (2018). Preservation of potential biosignatures in the shallow subsurface of Europa. Nat. Astron. 2, 673-679. doi: 10.1038/s41550-018-0499-8

Nordstrom, D. K., Alpers, C. N., Ptacek, C. J., and Blowes, D. W. (2000). Negative $\mathrm{pH}$ and extremely acidic mine waters from Iron Mountain, California. Environ. Sci. Technol. 34, 254-258. doi: 10.1021/es990646v

Nordstrom, D. K., Ball, J. W., and Mccleskey, R. B. (2005). "Ground water to surface water: chemistry of thermal outflows in Yellowstone National Park," in Geothermal Biology and Geochemistry in Yellowstone National Park, eds W. Inskeep and T. R. McDermott (Bozeman, MT: Montana State University), 73-94.

Norman, L. H. (2011). Is there life on ... Titan? Astron. Geophys. 52, 39-31. doi: $10.1111 /$ j.1468-4004.2011.52139.x
Oger, P. M., and Jebbar, M. (2010). The many ways of coping with pressure. Res. Microbiol. 161, 799-809. doi: 10.1016/j.resmic.2010.09.017

Ojha, L., Wilhelm, M. B., Murchie, S. L., McEwen, A. S., Wray, J. J., Hanley, J., et al. (2015). Spectral evidence for hydrated salts in recurring slope lineae on Mars. Nat. Geosci. 8, 829-832. doi: 10.1038/ngeo2546

Olson, G. J., Brierley, J. A., and Brierley, C. L. (2003). Bioleaching review part B: progress in bioleaching: applications of microbial processes by the minerals industries. Appl. Microbiol. Biotechnol. 63, 249-257. doi: 10.1007/s00253-0031404-6

Onofri, S., Selbmann, L., Pacelli, C., de Vera, J., Horneck, G., Hallsworth, J., et al. (2018). Integrity of the DNA and Cellular Ultrastructure of Cryptoendolithic Fungi in Space or Mars Conditions: a 1.5-Year Study at the International Space Station. Life 8:23. doi: 10.3390/life8020023

Oremland, R., Kulp, T., Blum, J., Hoeft, S., Baesman, S., Miller, L., et al. (2005). A microbial arsenic cycle in a salt-saturated, extreme environment. Science 308, 1305-1308. doi: 10.1126/science. 1110832

Oren, A. (2011). Thermodynamic limits to microbial life at high salt concentrations. Environ. Microbiol. 13, 1908-1923. doi: 10.1111/j.1462-2920. 2010.02365.x

Oren, A. (2013). "Life in magnesium- and calcium-rich hypersaline environments: salt stress By Chaotropic Ions," in Polyextremophiles. Cellular Origin, Life in Extreme Habitats and Astrobiology, eds J. Seckbach, A. Oren, and H. Stan-Lotter (Dordrecht: Springer), 215-232. doi: 10.1007/978-94-007-6488-0

Pandit, A. S., Joshi, M. N., Bhargava, P., Shaikh, I., Ayachit, G. N., Raj, S. R., et al. (2015). A snapshot of microbial communities from the Kutch: one of the largest salt deserts in the World. Extremophiles 19, 973-987. doi: 10.1007/s00792-0150772-z

Pankova, E. I., and Konyushkova, M. V. (2013). Climate and soil salinity in the deserts of Central Asia. Eurasian Soil Sci. 46, 721-727. doi: 10.1134/ S1064229313070065

Pasek, M. A., and Greenberg, R. (2012). Acidification of Europa's Subsurface Ocean as a Consequence of Oxidant Delivery. Astrobiology 12, 151-159. doi: 10.1089/ ast.2011.0666

Pavlov, A., Cheptsov, V., Tsurkov, D., Lomasov, V., Frolov, D., Vasiliev, G., et al. (2018). Survival of Radioresistant Bacteria on Europa's Surface after Pulse Ejection of Subsurface Ocean Water. Geosciences 9:9. doi: 10.3390/ geosciences 9010009

Phoenix, V. R., Bennett, P. C., Engel, A. S., Tyler, S. W., and Ferris, F. G. (2006). Chilean high-altitude hot-spring sinters: a model system for UV screening mechanisms by early Precambrian cyanobacteria. Geobiology 4, 15-28. doi: 10.1111/j.1472-4669.2006.00063.x

Picard, A., and Daniel, I. (2013). Pressure as an environmental parameter for microbial life - A review. Biophys. Chem. 183, 30-41. doi: 10.1016/j.bpc.2013. 06.019

Pikuta, E., Lysenko, A., Chuvilskaya, N., Mendrock, U., Hippe, H., Suzina, N., et al. (2000). Anoxybacillus pushchinensis gen. nov., sp. nov., a novel anaerobic, alkaliphilic, moderately thermophilic bacterium from manure, and description of Anoxybacillus flavithermus comb. nov. Int. J. Syst. Evol. Microbiol. 50, 2109-2117. doi: 10.1099/00207713-50-6-2109

Plümper, O., King, H. E., Geisler, T., Liu, Y., Pabst, S., Savov, I. P., et al. (2017). Subduction zone forearc serpentinites as incubators for deep microbial life. Proc. Natl. Acad. Sci. U.S.A. 114, 4324-4329. doi: 10.1073/pnas.1612147114

Pontefract, A., Zhu, T. F., Walker, V. K., Hepburn, H., Lui, C., Zuber, M. T., et al. (2017). Microbial diversity in a hypersaline sulfate lake: a terrestrial analog of ancient mars. Front. Microbiol. 8:1819. doi: 10.3389/fmicb.2017. 01819

Postberg, F., Kempf, S., Schmidt, J., Brilliantov, N., Beinsen, A., Abel, B., et al. (2009). Sodium salts in E-ring ice grains from an ocean below the surface of Enceladus. Nature 459, 1098-1101. doi: 10.1038/nature 08046

Postberg, F., Khawaja, N., Abel, B., Choblet, G., Glein, C. R., Gudipati, M. S., et al. (2018). Macromolecular organic compounds from the depths of Enceladus. Nature 558, 564-568. doi: 10.1038/s41586-018-0246-4

Price, P. B., and Sowers, T. (2004). Temperature dependence of metabolic rates for microbial growth, maintenance, and survival. Proc. Natl. Acad. Sci. U.S.A. 101, 4631-4636. doi: 10.1073/pnas.0400522101

Price, R. E., and Giovannelli, D. (2017). "A review of the geochemistry and microbiology of marine shallow-water hydrothermal vents," in Reference 
Module in Earth Systems and Environmental Sciences ed. S. A. Elias (Amsterdam: Elsevier).

Prieto, G. A., Froment, B., Yu, C., Poli, P., and Abercrombie, R. (2017). Earthquake rupture below the brittle-ductile transition in continental lithospheric mantle. Sci. Adv. 3:e1602642. doi: 10.1126/sciadv.1602642

Purcell, D., Sompong, U., Yim, L. C., Barraclough, T. G., Peerapornpisal, Y., and Pointing, S. B. (2007). The effects of temperature, $\mathrm{pH}$ and sulphide on the community structure of hyperthermophilic streamers in hot springs of northern Thailand. FEMS Microbiol. Ecol. 60, 456-466. doi: 10.1111/j.1574-6941.2007. 00302.x

Qi, J., Xu, M., An, C., Wu, M., Zhang, Y., Li, X., et al. (2017). Characterizations of geothermal springs along the Moxi deep fault in the western Sichuan plateau, China. Phys. Earth Planet. Inter. 263, 12-22. doi: 10.1016/j.pepi.2017.01.001

Quehenberger, J., Shen, L., Albers, S. V., Siebers, B., and Spadiut, O. (2017). Sulfolobus - A potential key organism in future biotechnology. Front. Microbiol. 8:2474. doi: $10.3389 /$ fmicb.2017.02474

Rainey, F. A., Ray, K., Ferreira, M., Gatz, B. Z., Nobre, M. F., Bagaley, D., et al. (2005). Extensive diversity of ionizing-radiation-resistant bacteria recovered from Sonoran Desert soil and description of nine new species of the genus Deinococcus obtained from a single soil sample. Appl. Environ. Microbiol. 71, 5225-5235. doi: 10.1128/AEM.71.9.5225-5235.2005

Reid, I. N., Sparks, W. B., Lubow, S., McGrath, M., Livio, M., Valenti, J., et al. (2006). Terrestrial models for extraterrestrial life: methanogens and halophiles at Martian temperatures. Int. J. Astrobiol. 5, 89-97. doi: 10.1017/ S1473550406002916

Resing, J. A., Baker, E. T., Lupton, J. E., Embley, R. W., Massoth, G. J., Chadwick, J. W., et al. (2007). Venting of acid-sulfate fluids in a high-sulfidation setting at NW Rota-1 submarine volcano on the Mariana Arc. Econ. Geol. 102, 10471061. doi: 10.2113 /gsecongeo.102.6.1047

Rivkina, E. M., Friedmann, E. I., McKay, C. P., and Gilichinsky, D. A. (2000). Metabolic activity of Permafrost Bacteria below the freezing point. Appl. Environ. Microbiol. 66, 3230-3233. doi: 10.1128/AEM.66.8.3230-3233.2000

Roadcap, G. S., Sanford, R. A., Jin, Q., Pardinas, J. R., and Bethke, C. M. (2006). Extremely alkaline $(\mathrm{pH}>12)$ ground water hosts diverse microbial community. Ground Water 44, 511-517. doi: 10.1111/j.1745-6584.2006.00199.x

Rohwerder, T., Gehrke, T., Kinzler, K., and Sand, W. (2003). Bioleaching review part A: progress in bioleaching: fundamentals and mechanisms of bacterial metal sulfide oxidation. Appl. Microbiol. Biotechnol. 63, 239-248. doi: 10.1007/ s00253-003-1448-7

Rosso, L., Lobry, J. R., Bajard, S., and Flandrois, J. P. (1995). Convenient model to describe the combined effects of temperature and $\mathrm{pH}$ on microbial growth. Appl. Environ. Microbiol. 61, 610-616.

Rothschild, L. J., and Mancinelli, R. L. (2001). Life in extreme environments. Nature 409, 1092-1101. doi: 10.1038/35059215

Rousk, J., Bååth, E., Brookes, P. C., Lauber, C. L., Lozupone, C., Caporaso, J. G., et al. (2010). Soil bacterial and fungal communities across a $\mathrm{pH}$ gradient in an arable soil. ISME J. 4, 1340-1351. doi: 10.1038/ismej.2010.58

Russell, M. J., Barge, L. M., Bhartia, R., Bocanegra, D., Bracher, P. J., Branscomb, E., et al. (2014). The drive to life on wet and icy worlds. Astrobiology 14, 308-343. doi: 10.1089 /ast.2013.1110

Russell, M. J., Hall, A. J., and Martin, W. (2010). Serpentinization as a source of energy at the origin of life. Geobiology 8, 355-371. doi: 10.1111/j.1472-4669. 2010.00249.x

Russell, M. J., Murray, A. E., and Hand, K. P. (2017). The possible emergence of life and differentiation of a shallow biosphere on irradiated icy worlds: the example of Europa. Astrobiology 17, 1265-1273. doi: 10.1089/ast.2016.1600

Samarkin, V. A., Madigan, M. T., Bowles, M. W., Casciotti, K. L., Priscu, J. C., McKay, C. P., et al. (2010). Abiotic nitrous oxide emission from the hypersaline Don Juan Pond in Antarctica. Nat. Geosci. 3, 341-344. doi: 10.1038/ ngeo847

Scambelluri, M., Piccardo, G., Philippot, P., Robbiano, A., and Negretti, L. (1997). High salinity fluid inclusions formed from recycled seawater in deeply subducted alpine serpentinite. Earth Planet. Sci. Lett. 148, 485-499. doi: 10. 1016/S0012-821X(97)00043-5

Scambos, T. A., Campbell, G. G., Pope, A., Haran, T., Muto, A., Lazzara, M., et al. (2018). Ultralow surface temperatures in East Antarctica from satellite thermal infrared mapping: the coldest places on earth. Geophys. Res. Lett. 45, 6124-6133. doi: $10.1029 / 2018$ GL078133
Schleper, C., Puehler, G., Holz, I., Gambacorta, A., Janekovic, D., Santarius, U., et al. (1995). Picrophilus gen. nov., fam. nov.: a novel aerobic, heterotrophic, thermoacidophilic genus and family comprising archaea capable of growth around pH 0. J. Bacteriol. 177, 7050-7059. doi: 10.1128/jb.177.24.7050-7059. 1995

Schleper, C., Puhler, G., Klenk, H.-P., and Zillig, W. (1996). Picrophilus oshimae and Picrophilus torridus fam. nov., gen. nov., sp. nov., two species of hyperacidophilic, thermophilic, heterotrophic, aerobic archaea. Int. J. 46, 814-816. doi: 10.1099/00207713-46-3-814

Schrenk, M. O., Brazelton, W. J., and Lang, S. Q. (2013). Serpentinization, carbon, and deep life. Rev. Mineral. Geochem. 75, 575-606. doi: 10.2138/rmg.2013.75.18

Schrenk, M. O., Edwards, K. J., Goodman, R. M., Hamers, R. J., and Banfield, J. F. (1998). Distribution of Thiobacillus ferrooxidans and Leptospirillum ferrooxidans: implications for generation of acid mine drainage. Science 279, 1519-1522. doi: 10.1126/science.279.5356.1519

Schuerger, A. C., Mancinelli, R. L., Kern, R. G., Rothschild, L. J., and McKay, C. P. (2003). Survival of endospores of Bacillus subtilis on spacecraft surfaces under simulated martian environments: implications for the forward contamination of Mars. Icarus 165, 253-276. doi: 10.1016/S0019-1035(03)00200-8

Schuerger, A. C., and Nicholson, W. L. (2016). Twenty species of hypobarophilic bacteria recovered from diverse soils exhibit growth under simulated Martian conditions at $0.7 \mathrm{kPa}$. Astrobiology 16, 964-976. doi: 10.1089/ast.2016.1587

Schulze-Makuch, D. (2013). "Extremophiles on alien worlds: what types of organismic adaptations are feasible on other planetary bodies," in Habitability of Other Planets and Satellites, eds J.-P. de Vera and J. Seckbach (Berlin: Springer), 253-265. doi: 10.1007/978-94-007-6546-7_14

Schulze-Makuch, D., Airo, A., and Schirmack, J. (2017). The adaptability of life on earth and the diversity of planetary habitats. Front. Microbiol. 8:2011. doi: 10.3389/fmicb.2017.02011

Schulze-Makuch, D., Grinspoon, D. H., Abbas, O., Irwin, L. N., and Bullock, M. A. (2004). A sulfur-based survival strategy for putative phototrophic life in the venusian atmosphere. Astrobiology 4, 11-18. doi: 10.1089/153110704773600203

Schwieterman, E. W., Kiang, N. Y., Parenteau, M. N., Harman, C. E., DasSarma, S., Fisher, T. M., et al. (2018). Exoplanet biosignatures: a review of remotely detectable signs of life. Astrobiology 18, 663-708. doi: 10.1089/ast.2017.1729

Seager, S. (2013). Exoplanet habitability. Science 340, 577-581. doi: 10.1126/science. 1232226

Seckbach, J., Oren, A., and Stan-Lotter, H. (eds) (2013). Polyextremophiles. Dordrecht: Springer. doi: 10.1007/978-94-007-6488-0

Segerer, A., Neuner, A., Kristjansson, J. K., and Stetter, K. O. (1986). Acidianus infernus gen. nov., sp. nov., and Acidianus brierleyi Comb. nov.: facultatively aerobic, extremely acidophilic thermophilic sulfur-metabolizing archaebacteria. Int. J. Syst. Bacteriol. 36, 559-564. doi: 10.1099/00207713-36-4-559

Sghaier, H., Thorvaldsen, S., and Saied, N. M. (2013). There are more small amino acids and fewer aromatic rings in proteins of ionizing radiation-resistant bacteria. Ann. Microbiol. 63, 1483-1491. doi: 10.1007/s13213-013-0612-2

Sharma, A., Scott, J. H., Cody, G. D., Fogel, M. L., Hazen, R. M., Hemley, R. J., et al. (2002). Microbial activity at gigapascal pressures. Science 295, 1514-1516. doi: $10.1126 /$ science. 1068018

Sharp, C. E., Brady, A. L., Sharp, G. H., Grasby, S. E., Stott, M. B., and Dunfield, P. F. (2014). Humboldt's spa: microbial diversity is controlled by temperature in geothermal environments. ISME J. 8, 1166-1174. doi: 10.1038/ismej.2013.237

Shock, E. L., and Boyd, E. S. (2015). Principles of geobiochemistry. Elements 11, 395-401. doi: 10.2113/gselements.11.6.395

Siegert, M. J., Ellis-Evans, J. C., Tranter, M., Mayer, C., Petit, J. R., Salamatin, A., et al. (2001). Physical, chemical and biological processes in Lake Vostok and other Antarctic subglacial lakes. Nature 414, 603-609. doi: 10.1038/ 414603a

Singh, D., Takahashi, K., Kim, M., Chun, J., and Adams, J. M. (2012). A Hump-backed trend in bacterial diversity with elevation on Mount Fuji, Japan. Microb. Ecol. 63, 429-437. doi: 10.1007/s00248-0119900-1

Sinha, N., Nepal, S., Kral, T., and Kumar, P. (2017). Survivability and growth kinetics of methanogenic archaea at various $\mathrm{pHs}$ and pressures: implications for deep subsurface life on Mars. Planet. Space Sci. 136, 15-24. doi: 10.1016/j. pss.2016.11.012

Smith, D. J., Schuerger, A. C., Davidson, M. M., Pacala, S. W., Bakermans, C., and Onstott, T. C. (2009). Survivability of Psychrobacter cryohalolentis K5 under 
simulated martian surface conditions. Astrobiology 9, 221-228. doi: 10.1089/ast. 2007.0231

Soderlund, K. M., Schmidt, B. E., Wicht, J., and Blankenship, D. D. (2014). Oceandriven heating of Europa's icy shell at low latitudes. Nat. Geosci. 7, 16-19. doi: 10.1038/ngeo2021

Sohl, F., Solomonidou, A., Wagner, F. W., Coustenis, A., Hussmann, H., and Schulze-Makuch, D. (2014). Structural and tidal models of Titan and inferences on cryovolcanism. J. Geophys. Res. Planets 119, 1013-1036. doi: 10.1002/ 2013JE004512

Spencer, J. R., Tamppari, L. K., Martin, T. Z., and Travis, L. D. (1999). Temperatures on Europa from Galileo photopolarimeter-radiometer: nighttime thermal anomalies. Science 284, 1514-1516. doi: 10.1126/science.284.54 19.1514

Steinle, L., Knittel, K., Felber, N., Casalino, C., De Lange, G., Tessarolo, C., et al. (2018). Life on the edge: active microbial communities in the Kryos $\mathrm{MgCl} 2$ brine basin at very low water activity. ISME J. 12, 1414-1426. doi: 10.1038/ s41396-018-0107-z

Stetter, K. O. (1982). Ultrathin mycelia-forming organisms from submarine volcanic areas having an optimum growth temperature of $105^{\circ} \mathrm{C}$. Nature 300 , 258-260. doi: 10.1038/300258a0

Stevenson, A., Cray, J. A., Williams, J. P., Santos, R., Sahay, R., Neuenkirchen, N., et al. (2015). Is there a common water-activity limit for the three domains of life. ISME J. 9, 1333-1351. doi: 10.1038/ismej.2014.219

Suzuki, S., Ishii, S., Wu, A., Cheung, A., Tenney, A., Wanger, G., et al. (2013). Microbial diversity in The Cedars, an ultrabasic, ultrareducing, and low salinity serpentinizing ecosystem. Proc. Natl. Acad. Sci. U.S.A. 110, 15336-15341. doi: $10.1073 /$ pnas. 1302426110

Suzuki, S., Kuenen, J. G., Schipper, K., Van Der Velde, S., Ishii, S., Wu, A., et al. (2014). Physiological and genomic features of highly alkaliphilic hydrogen-utilizing Betaproteobacteria from a continental serpentinizing site. Nat. Commun. 5:3900. doi: 10.1038/ncomms4900

Swan, B. K., Ehrhardt, C. J., Reifel, K. M., Moreno, L. I., and Valentine, D. L. (2010). Archaeal and bacterial communities respond differently to environmental gradients in anoxic sediments of a California hypersaline lake, the Salton Sea. Appl. Environ. Microbiol. 76, 757-768. doi: 10.1128/AEM.02409-09

Takai, K., Nakamura, K., Toki, T., Tsunogai, U., Miyazaki, M., Miyazaki, J., et al. (2008). Cell proliferation at $122 \mathrm{C}$ and isotopically heavy $\mathrm{CH} 4$ production by a hyperthermophilic methanogen under high-pressure cultivation. Proc. Natl. Acad. Sci. U.S.A. 105, 10949-10954. doi: 10.1073/pnas.0712334105

Tambekar, D. H., Pawar, A. L., and Dudhane, M. N. (2010). Lonar lake water: past and present. Nat. Envion. Pollut. Tech. 9, 217-221.

Taran, Y. A. (2009). Geochemistry of volcanic and hydrothermal fluids and volatile budget of the Kamchatka-Kuril subduction zone. Geochim. Cosmochim. Acta 73, 1067-1094. doi: 10.1016/j.gca.2008.11.020

Taubner, R. S., Pappenreiter, P., Zwicker, J., Smrzka, D., Pruckner, C., Kolar, P., et al. (2018). Biological methane production under putative Enceladus-like conditions. Nat. Commun. 9:748. doi: 10.1038/s41467-01802876-y

Teolis, B. D., Wyrick, D. Y., Bouquet, A., Magee, B. A., and Waite, J. H. (2017). Plume and surface feature structure and compositional effects on Europa's global exosphere: preliminary Europa mission predictions. Icarus 284, 18-29. doi: 10.1016/j.icarus.2016.10.027

Toner, J. D., Catling, D. C., and Sletten, R. S. (2017). The geochemistry of Don Juan Pond: evidence for a deep groundwater flow system in Wright Valley Antarctica. Earth Planet. Sci. Lett. 474, 190-197. doi: 10.1016/j.epsl.2017. 06.039

Torii, T., Murata, S., and Yamagata, N. (1981). Geochemistry of the Dry Valley lakes. J. R. Soc. New Zeal. 11, 387-399. doi: 10.1080/03036758.1981.10423329

Trapeznikov, A. (1983). Radioactivity in the Canadian environment. Natl. Res. Counc. Canada 19250:292.

Travis, B. J., Palguta, J., and Schubert, G. (2012). A whole-moon thermal history model of Europa: impact of hydrothermal circulation and salt transport. Icarus 218, 1006-1019. doi: 10.1016/j.icarus.2012.02.008

Tutu, H., McCarthy, T. S., and Cukrowska, E. (2008). The chemical characteristics of acid mine drainage with particular reference to sources, distribution and remediation: the Witwatersrand Basin, South Africa as a case study. Appl. Geochem. 23, 3666-3684. doi: 10.1016/j.apgeochem.2008. 09.002
Van Der Wielen, P. W. J. J., Bolhuis, H., Borin, S., Daffonchio, D., Corselli, C., Giuliano, L., et al. (2005). The enigma of prokaryotic life in deep hypersaline anoxic basins. Science 307, 121-123. doi: 10.1126/science.1103569

Van Dover, C. L., Humphris, S. E., Fornari, D., Cavanaugh, C. M., Collier, R., Goffredi, S. K., et al. (2001). Biogeography and ecological setting of Indian Ocean hydrothermal vents. Science 294, 818-823. doi: 10.1126/science.1064574

Vance, S. D., Hand, K. P., and Pappalardo, R. T. (2016). Geophysical controls of chemical disequilibria in Europa. Geophys. Res. Lett. 43, 4871-4879. doi: 10.1002/2016GL068547.Received

Vanlint, D., Mitchell, R., Bailey, E., Meersman, F., McMillan, P. F., Michiels, C. W., et al. (2011). Rapid acquisition of gigapascal-high-pressure resistance by Escherichia coli. mBio 2:e00130-10. doi: 10.1128/mBio.00130-10

Varnes, E. S., Jakosky, B. M., and McCollom, T. M. (2003). Biological potential of Martian hydrothermal systems. Astrobiology 3, 407-414. doi: 10.1089/ 153110703769016479

Villarreal, M. N., Russell, C. T., Luhmann, J. G., Thompson, W. T., Prettyman, T. H., A'Hearn, M. F., et al. (2017). The dependence of the cerean exosphere on solar energetic particle events. Astrophys. J. 838:L8. doi: 10.3847/2041-8213/ aa66cd

Vu, T. H., Hodyss, R., Johnson, P. V., and Choukroun, M. (2017). Preferential formation of sodium salts from frozen sodium-ammonium-chloride-carbonate brines - Implications for Ceres' bright spots. Planet. Space Sci. 141, 73-77. doi: 10.1016/j.pss.2017.04.014

Waite, J. H., Lewis, W. S., Magee, B. A., Lunine, J. I., McKinnon, W. B., Glein, C. R., et al. (2009). Liquid water on Enceladus from observations of ammonia and40Ar in the plume. Nature 460, 487-490. doi: 10.1038/nature08153

Waldron, P. J., Petsch, S. T., Martini, A. M., and Nüslein, K. (2007). Salinity constraints on subsurface archaeal diversity and methanogenesis in sedimentary rock rich in organic matter. Appl. Environ. Microbiol. 73, 4171-4179. doi: 10.1128/AEM.02810-06

Walsh, E. A., Kirkpatrick, J. B., Rutherford, S. D., Smith, D. C., Sogin, M., and D'Hondt, S. (2016). Bacterial diversity and community composition from seasurface to subseafloor. ISME J. 10, 979-989. doi: 10.1038/ismej.2015.175

Wayne, R. P. (2000). Chemistry of Atmospheres, 3rd Edn. Oxford: Clarendon Press.

Webb, K. M., and DiRuggiero, J. (2013). "Radiation resistance in extremophiles: fending off multiple attacks," in Polyextremophiles: Life Under Multiple Forms of Stress, eds J. Seckbach, A. Oren, and H. Stan-Lotter (Dordrecht: Springer), 249-267. doi: 10.1007/978-94-007-6488-0_10

Weiss, B. P., Fong, L. E., Vali, H., Lima, E. A., and Baudenbacher, F. J. (2008). Paleointensity of the ancient Martian magnetic field. Geophys. Res. Lett. 35:L23207. doi: 10.1029/2008GL035585

Wheeler, K. A., Hurdman, B. F., and Pitt, J. I. (1991). Influence of pH on the growth of some toxigenic species of Aspergillus, Penicillium and Fusarium. Int. J. Food Microbiol. 12, 141-149. doi: 10.1016/0168-1605(91)90063-U

Wordsworth, R. (2016). The climate of early mars. Annu. Rev. Earth Planet. Sci. 44, 381-408. doi: 10.1146/annurev-earth-060115-012355

Xiao, X., Wang, P., Zeng, X., Bartlett, D. H., and Wang, F. (2007). Shewanella psychrophila sp. nov. and Shewanella piezotolerans sp. nov., isolated from west Pacific deep-sea sediment. Int. J. Syst. Evol. Microbiol. 57, 60-65. doi: 10.1099/ ijs.0.64500-0

Xiong, J., Liu, Y., Lin, X., Zhang, H., Zeng, J., Hou, J., et al. (2012). Geographic distance and $\mathrm{pH}$ drive bacterial distribution in alkaline lake sediments across Tibetan Plateau. Environ. Microbiol. 14, 2457-2466. doi: 10.1111/j.1462-2920. 2012.02799.x

Yakimov, M. M., La Cono, V., Slepak, V. Z., La Spada, G., Arcadi, E., Messina, E., et al. (2013). Microbial life in the Lake Medee, the largest deep-sea salt-saturated formation. Sci. Rep. 3:3554. doi: 10.1016/0301-0104(89) 87026-0

Yakimov, M. M., La Cono, V., Spada, G. L., Bortoluzzi, G., Messina, E., Smedile, F., et al. (2015). Microbial community of the deep-sea brine Lake Kryos seawaterbrine interface is active below the chaotropicity limit of life as revealed by recovery of mRNA. Environ. Microbiol. 17, 364-382. doi: 10.1111/1462-2920. 12587

Yamagishi, A., Kawaguchi, Y., Hashimoto, H., Yano, H., Imai, E., Kodaira, S., et al. (2018). Environmental data and survival data of Deinococcus aetherius from the exposure facility of the Japan experimental module of the international space station obtained by the tanpopo mission. Astrobiology 18, 1369-1374. doi: 10.1089 /ast.2017.1751 
Yang, J., Ma, L., Jiang, H., Wu, G., and Dong, H. (2016). Salinity shapes microbial diversity and community structure in surface sediments of the Qinghai-Tibetan Lakes. Sci. Rep. 6:25078. doi: 10.1038/srep25078

Yayanos, A. A., Dietz, A. S., and Van Boxtel, R. (1981). Obligately barophilic bacterium from the Mariana trench. Proc. Natl. Acad. Sci. U.S.A. 78, 5212-5215. doi: $10.1073 /$ pnas.78.8.5212

Zhalnina, K., Dias, R., de Quadros, P. D., Davis-Richardson, A., Camargo, F. A. O., Clark, I. M., et al. (2014). Soil pH determines microbial diversity and composition in the park grass experiment. Microb. Ecol. 69, 395-406. doi: 10.1007/s00248-014-0530-2

Zhang, L., Su, F., Kong, X., Lee, F., Day, K., Gao, W., et al. (2016). Ratiometric fluorescent $\mathrm{pH}$-sensitive polymers for high-throughput monitoring of extracellular pH. RSC Adv. 6, 46134-46142. doi: 10.1039/c6ra $06468 \mathrm{j}$

Zhou, Z., Jiang, F., Wang, S., Peng, F., Dai, J., Li, W., et al. (2012). Pedobacter arcticus sp. nov., a facultative psychrophile isolated from Arctic soil, and emended descriptions of the genus Pedobacter, Pedobacter heparinus, Pedobacter daechungensis, Pedobacter terricola, Pedobacter glucosidilyticus and Pedobacter lentus. Int. J. Syst. Evol. Microbiol. 62, 1963-1969. doi: 10.1099/ijs.0. 031104-0

Zhu, P., Manucharyan, G. E., Thompson, A. F., Goodman, J. C., and Vance, S. D. (2017). The influence of meridional ice transport on Europa's ocean stratification and heat content. Geophys. Res. Lett. 44, 5969-5977. doi: 10.1002/ 2017GL072996
Zolotov, M. Y. (2009). On the composition and differentiation of Ceres. Icarus 204, 183-193. doi: 10.1016/j.icarus.2009.06.011

Zolotov, M. Y. (2017). Aqueous origins of bright salt deposits on Ceres. Icarus 296, 289-304. doi: 10.1016/j.icarus.2017.06.018

Zolotov, M. Y., and Kargel, J. S. (2009). "On the chemical composition of Europa's icy shell, ocean, and underlying rocks," in Europa, eds R. T. Pappalardo, W. B. McKinnon, and K. Khurana (Tucson, AZ: University of Arizona Press), 431.

Zolotov, M. Y., Tobie, G., Postberg, F., Magee, B., Waite, J. H., and Esposito, L. (2011). Chemical and phase composition of Enceladus: insights from Cassini data. EPSC Abstracts 6:EPSC-DPS2011-1330. doi: 10.1029/2011GL0 47415

Conflict of Interest Statement: The authors declare that the research was conducted in the absence of any commercial or financial relationships that could be construed as a potential conflict of interest.

Copyright (c) 2019 Merino, Aronson, Bojanova, Feyhl-Buska, Wong, Zhang and Giovannelli. This is an open-access article distributed under the terms of the Creative Commons Attribution License (CC BY). The use, distribution or reproduction in other forums is permitted, provided the original author(s) and the copyright owner(s) are credited and that the original publication in this journal is cited, in accordance with accepted academic practice. No use, distribution or reproduction is permitted which does not comply with these terms. 